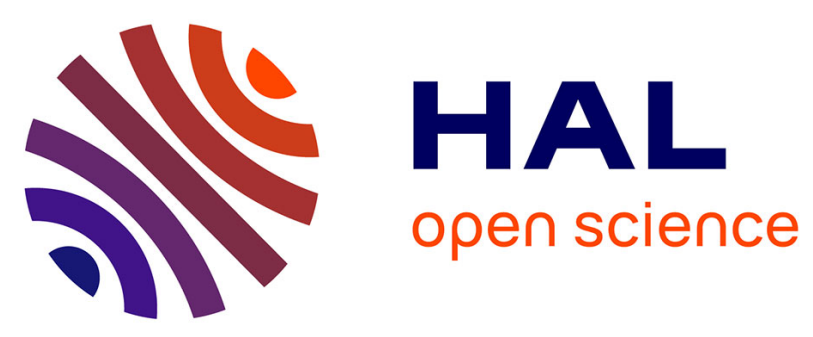

\title{
Triterpenoid saponins and other glycosides from the stems and bark of Jaffrea xerocarpa and their biological activity
}

Dima Muhammad, Nathalie Lalun, Hélène Bobichon, Elisabeth Le Magrex

Debar, Sophie C. Gangloff, Mohammed Nour, Laurence

Voutquenne-Nazabadioko

\section{To cite this version:}

Dima Muhammad, Nathalie Lalun, Hélène Bobichon, Elisabeth Le Magrex Debar, Sophie C. Gangloff, et al.. Triterpenoid saponins and other glycosides from the stems and bark of Jaffrea xerocarpa and their biological activity. Phytochemistry, 2017, 141, pp.121-130. 10.1016/j.phytochem.2017.05.018 . hal-01996283

\section{HAL Id: hal-01996283 \\ https://hal.univ-reims.fr/hal-01996283}

Submitted on 28 Oct 2021

HAL is a multi-disciplinary open access archive for the deposit and dissemination of scientific research documents, whether they are published or not. The documents may come from teaching and research institutions in France or abroad, or from public or private research centers.
L'archive ouverte pluridisciplinaire HAL, est destinée au dépôt et à la diffusion de documents scientifiques de niveau recherche, publiés ou non, émanant des établissements d'enseignement et de recherche français ou étrangers, des laboratoires publics ou privés. 


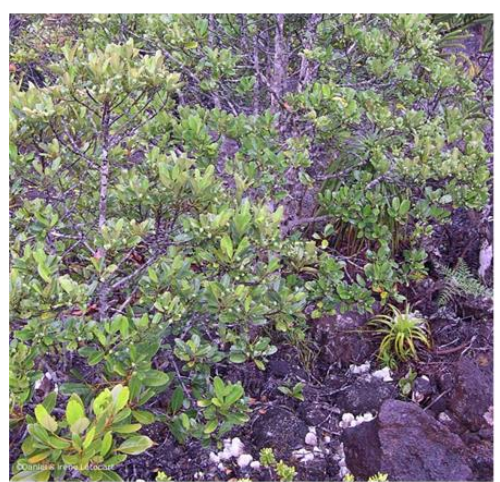

Jaffrea xerocarpa

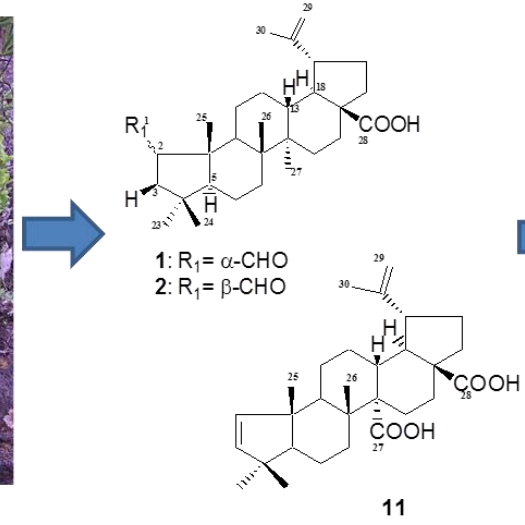

11
Antioxidant activity of the

hydromethanolic extract $\left(\mathrm{EC}_{50}=\right.$ $73 \mu \mathrm{g} / \mathrm{mL}$ )

Antimicrobial activity of $\mathbf{1}$

against $S$. aureus and E. faecalis (MIC $4 \mu \mathrm{g} / \mathrm{mL}$ )

Cytotoxic activity against a $\mathrm{KB}$ cell line of $\mathbf{1 1}\left(\mathrm{IC}_{50} 2.6 \mu \mathrm{M}\right)$ and 1-2 and $12\left(\mathrm{IC}_{50}\right.$ from 7.0 to 8.5 $\mu \mathrm{M})$

\section{Highlights}

- Five dammarane triterpenoid glycosides were isolated from Jaffrea xerocarpa.

Three norlupane triterpenoids were isolated from Jaffrea xerocarpa.

The hydromethanolic extract showed good antioxidant activity (DPPH assay)

A norlupane triterpenoid showed antibacterial activity.

Three lupane triterpenoids showed good cytotoxic activity against KB cells. 
Triterpenoid saponins and other glycosides from the stems and bark of Jaffrea xerocarpa and their biological activity.

Dima Muhammad $^{\mathrm{a}}$, Nathalie Lalun ${ }^{\mathrm{b}}$, Hélène Bobichon ${ }^{\mathrm{b}}$, Elisabeth Le Magrex Debar ${ }^{\mathrm{c}}$, Sophie C.

Gangloff $^{\mathrm{c}}$, Mohammed Nour $^{\mathrm{d}}$ and Laurence Voutquenne-Nazabadioko ${ }^{\mathrm{a} *}$

${ }^{a}$ UMR CNRS 7312, Université de Reims Champagne-Ardenne, Bât. 18, Moulin de la Housse, BP 1039, 51687 Reims, Cedex 2, France

${ }^{\mathrm{b}}$ CNRS FRE 3481, Université de Reims Champagne Ardenne, 51 rue Cognacq-Jay, 51095 Reims cedex, France

${ }^{\mathrm{c}}$ Laboratoire de Microbiologie, EA 4691, UFR de Pharmacie, 1 Rue du Maréchal Juin, 51096 Reims Cedex, France.

d Laboratoire Insulaire du Vivant et de l'Environnement (LIVE), EA 4243, Université de la NouvelleCalédonie, BP R4, 98851 Nouméa Cedex, Nouvelle-Calédonie

*Correspondance to: L. Voutquenne-Nazabadioko, UMR CNRS 7312, Université de Reims Champagne-Ardenne, Bât. 18, Moulin de la Housse, BP 103951687 Reims, Cedex 2, France. Tel.: +33-3-26-91-82-09; Email: laurence.nazabadioko@ univ-reims.fr 


\begin{abstract}
:
Six previously undescribed triterpenoid saponins and two previously undescribed norlupane triterpenes were isolated with five known saponins, three known lupane derivatives, 17,20-didehydro-20deoxyjujubogenin, rutin, ( \pm ) 3 $\alpha$ - $O$ - $\beta$-D-glucopyranosyl-lyoniresinol, ( \pm ) 4- $O$ - $\beta$-D-glucopyranosylmaesopsin, three phenol glycosides, and uridine from the stems and bark of Jaffrea xerocarpa (Baill.) H. C. Hopkins \& Pillon (= Basionym Alphitonia xerocarpus Baill.) (Rhamnaceae), an endemic tree of New Caledonia. The chemical structures of the purified compounds were identified by nuclear magnetic resonance and mass spectrometry. The isolated compounds were tested for their antioxidant, antityrosinase, antibacterial and cytotoxic activities. The aqueous methanol extract showed antioxidant activity (DPPH assay) due to the presence of rutin and other phenolic compounds. Three lupane triterpenes showed good cytotoxic activities against $\mathrm{KB}$ cells line ( $\mathrm{IC}_{50}$ from 7.7 to $8.5 \mu \mathrm{M}$ ). The previously undescribed $2 \alpha$-formyl-A(1)norlup-20(29)-en-28-oic acid showed antibacterial activity against Staphylococcus aureus and Enterococcus faecalis with both MIC values of $4 \mu \mathrm{g} / \mathrm{mL}$.
\end{abstract}

Keywords: Jaffrea xerocarpa, Alphitonia xerocarpus; Rhamnaceae; stem; bark; triterpenoids; dammarane; norlupane 


\section{INTRODUCTION}

New Caledonia is a global biodiversity "hotspot", characterized by $77.8 \%$ of endemic plants. The flora comprises 126 families of dicotyledons, with 490 genera and 2491 species from which 2108 species (84.5\% of the total) and 77 genera $(15.7 \%)$ are endemic. The 77 endemic genera belong to 36 families and comprise 366 species, only 17.3\% of the total (Morat et al., 2012). Ten species are included in the Rhamnaceae family (Munzinger et al. 2016), three of which are Alphitonia species (A. neocaledonica (Schltr.) Guillaumin, A. xerocarpus Baill. and A. erubescens Baill.) (Guillaumin, 1948). Recently, molecular phylogenetic and morphological data show that two of these species firstly described by Baillon (1876), A. xerocarpus and A. erubescens, are misplaced. Consequently, a new genus, Jaffrea $\mathrm{H}$. C. Hopkins \& Pillon, was described, and these species were renamed as Jaffrea xerocarpa (Baill.) H. C. Hopkins \& Pillon and Jaffrea erubescens (Baill.) H. C. Hopkins \& Pillon (Hopkins et al., 2015). Members of this new genus have a conical hypanthium, petals somewhat incurved at anthesis, a thick disc that is either \pm lumpy or annular but not or only partly covering the semi-inferior ovary, and fruits that are ovoid-ellipsoid, strongly beaked and tardily dehiscent. Jaffrea can be distinguished from Alphitonia s.s., in which the seeds often persist on the receptacle after dehiscence (Hopkins et al., 2015). Jaffrea xerocarpa (Baill.) H. C. Hopkins \& Pillon (= Basionym Alphitonia xerocarpus Baill) is a shrub or small forest tree widely distributed on the main island of Grande Terre, growing on the ultramafic substrates of New Caledonia at an altitude of 800-900 meters (Baillon, 1876). In a continuation of the study of New-Caledonian species (Muhammad et al., 2015, Muhammad et al., 2016), we investigated the specialized metabolite profile of J. xerocarpa stem and bark. A recent study on Alphitonia neocaledonica leaves and fruits showed the presence of flavonoids, betulinic acid, alphitolic acid, corosolic acid, and (+) gallocatechin (Lin et al., 1995, Muhammad et al., 2015). A previous study on A. xerocarpus $(=$ J. xerocarpa) leaves from New-Caledonia, showed the presence of thirteen triterpenoid saponins, two norlupane triterpenoids (ceanothic acid and 29-hydroxyceanothic acid) and four flavonoids (Muhammad et al., 2016). The triterpenoid saponins are lupane or dammarane saponins, including derivatives of jujubogenin and 16,17-secodammarane. In addition in vitro cytotoxic, antiinflammatory, and antimicrobial activity (Dzuback et al., 2006, Muhammad et al., 2015, Muhammad et $a l ., 2016$ ) of the isolated compounds were measured. Turning our attention to the stems and bark of $J$. xerocarpa, a further eight previously undescribed (1-8), and sixteen known (9-24) compounds were found, eight of which (10-11, 13-18), were previously isolated from the leaves (Muhammad et al., 2016). The radical scavenging ability of the extracts was investigated, as well as the tyrosinase inhibitory activity, the cytotoxic activity against KB cells and the antibacterial activity of some of the isolated compounds. 


\section{Results and discussion}

The powdered bark of Jaffrea xerocarpa was macerated and extracted successively with petroleum ether and EtOAc and then refluxed with a mixture of $\mathrm{CH}_{3} \mathrm{OH}-\mathrm{H}_{2} \mathrm{O}(8: 2)$ to give three extracts. The EtOAc extract was fractionated by silica gel column chromatography to give a previously undescribed lupane triterpene (1) as the major compound, together with the known ceanothic acid (10) (Kundu et al., 1989, Jou et al., 2004), ceanothenic acid (11) (Jou et al., 2004, Ji et al., 2012) previously isolated from the leaves (Muhammad et al., 2016), and alphitolic acid (12) (Lee et al., 2003) (Fig. 1).

The powdered stems of $J$. xerocarpa were refluxed with a mixture of $\mathrm{CH}_{3} \mathrm{OH}-\mathrm{H}_{2} \mathrm{O}(8: 2)$ to give the aqueous methanol extract. This extract was subjected to multiple chromatographic steps over silica gel and RP-C 18 yielding eight previously undescribed compounds (1-8) with the aglycon of compounds 4-8, the 17,20-didehydro-20-deoxyjujubogenin (9), isolated for the first time alone, and fifteen known compounds (10-24). All compounds were identified by extensive spectroscopic methods including 1D$\left({ }^{1} \mathrm{H}\right.$ and $\left.{ }^{13} \mathrm{C}\right)$ and 2D-NMR (COSY, TOCSY, $J$-modulated HSQC, HMBC and ROESY) experiments as well as HRESIMS analysis and by comparison with spectral data from the literature values for the known compounds. The known compounds from the stems were identified as three lupane triterpenes, ceanothic acid (10) (Kundu et al., 1989), ceanothenic acid (11) (Jou et al., 2004), and alphitolic acid (12) (Lee et al., 2003), five saponins previously isolated from the leave, 3-O- $\alpha$-L-rhamnopyranosyl-(1 $\rightarrow 2)-[\beta$-D-

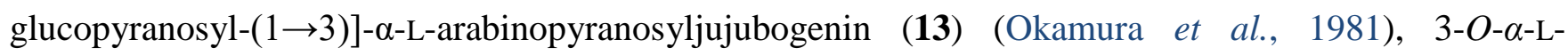
rhamnopyranosyl- $(1 \rightarrow 2)$-[4- $O$-(sodium sulfonato)- $\beta$-D-glucopyranosyl-( $(1 \rightarrow 3)]-\alpha$-Larabinopyranosyljujubogenin (14) (Muhammad et al., 2016), 3-O- $\beta$-D-glucopyranosyl-(1 $\rightarrow 2$ )- $\beta$-Dglucopyranosyl-( $(1 \rightarrow 3)$-[ $\alpha$-L-rhamnopyranosyl-( $(1 \rightarrow 2)]-\alpha$-L-arabinopyranosyljujubogenin (15) (Wang et al., 2013), 3-O- $\beta$-D-xylopyranosyl-( $1 \rightarrow 6)-\beta$-D-glucopyranosyl-( $1 \rightarrow 2)-\beta$-D-glucopyranosyl-( $1 \rightarrow 3)$-[ $\alpha-\mathrm{L}$ rhamnopyranosyl-(1 $\rightarrow 2)$ ]- $\alpha$-L-arabinopyranosyljujubogenin (16) (Muhammad et al., 2016), and 3-O- $\alpha$ -

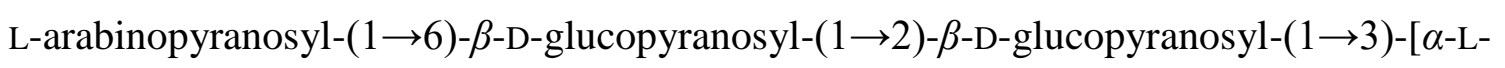

rhamnopyranosyl-(1 $\rightarrow 2)$ ]- $\alpha$-L-arabinopyranosyljujubogenin (17) (Muhammad et al., 2016) (Fig. 1), and rutin (18) (Lallemand et al., 1977, Li et al., 2008), a flavonoid also previously isolated from the leaves (Muhammad et al., 2016). Other specialized metabolites isolated from the stems include three known phenol glycosides, 1-O- $\beta$-D-glucopyranosyl-4-(8-hydroxyethyl)-2-methoxyphenyl (19) (Kuo and Shue, 1991), 1-O- $\beta$-D-glucopyranosyl-5-(8-hydroxyethyl)-phenyl (20) (Sugiyama and Kikuchi, 1992), and 1-O-

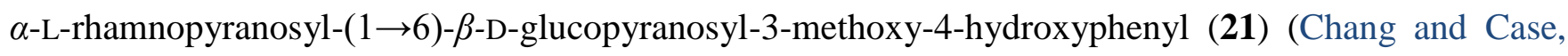
2005), a lignan, ( \pm ) 3 $\alpha$ - $O$ - $\beta$-D-glucopyranosyl-lyoniresinol (22), ( \pm )-4- $O$ - $\beta$-D-glucopyranosyl-maesopsine (23) (Yoshikawa et al., 1998), and uridine (24) (Pretsch et al., 1989) (Fig. 1). 
Acid hydrolysis of the aqueous methanol extract afforded four sugar units in the aqueous layer, identified by HPLC analysis on a chiral column (Lopes and Gaspar, 2008, Muhammad et al., 2016), as D-glucose (Glc), D-xylose (Xyl), L-arabinose (Ara) and L-rhamnose (Rha).

Compound 1 was obtained as a white amorphous powder. The positive HRESIMS spectrum of 1 showed a pseudomolecular ion peak at $m / z 477.3339\left([\mathrm{M}+\mathrm{Na}]^{+}\right.$, calcd for $\left.\mathrm{C}_{30} \mathrm{H}_{46} \mathrm{O}_{3} \mathrm{Na}, 477.3345\right)$ corresponding to the molecular formula $\mathrm{C}_{30} \mathrm{H}_{46} \mathrm{O}_{3}$. The ${ }^{1} \mathrm{H}$ NMR spectrum of 1 showed signals of a lupane triterpene characterized by six tertiary methyl groups at $\delta_{\mathrm{H}} 0.96\left(6 \mathrm{H}, \mathrm{H}_{3}-26\right.$ and $\left.\mathrm{H}_{3}-27\right), 0.97\left(\mathrm{H}_{3}-24\right), 0.99\left(\mathrm{H}_{3}-25\right)$, $1.12\left(\mathrm{H}_{3}-23\right)$, and $1.70\left(\mathrm{H}_{3}-30\right)$, an exomethylene group at $\delta_{\mathrm{H}} 4.64\left(\mathrm{~d}, J=2.2,1.5 \mathrm{~Hz}, \mathrm{H}_{\mathrm{a}}-29\right)$ and $4.75, \mathrm{~d}$, $\left.J=2.2 \mathrm{~Hz}, \mathrm{H}_{\mathrm{b}}-29\right)$, and an aldehyde group at $\delta_{\mathrm{H}} 9.84(\mathrm{~d}, J=3.5 \mathrm{~Hz})$. Its ${ }^{13} \mathrm{C}$ NMR spectrum exhibited 30 carbon signals including an aldehyde group $\left(\delta_{\mathrm{C}} 205.3\right)$, a carboxyl group $\left(\delta_{\mathrm{C}} 181.9\right)$, and an exomethylene $\left(\delta_{\mathrm{C}} 109.9\right.$ and 150.2) (Table 1). Analysis of the COSY, $J$-modulated HSQC and HMBC spectra and comparison of these data with the literature revealed that the spectroscopic data of $\mathbf{1}$ were similar to those of zizyberanalic acid (Kundu et al., 1989). The only difference lay in the absence of a hydroxyl group attached to C-3. This was readily confirmed by COSY correlations between the proton signal of the aldehyde $\left(\delta_{\mathrm{H}} 9.84, \mathrm{H}-1\right)$ and the proton signal at $\delta_{\mathrm{H}} 2.58(\mathrm{dd}, J=7.8,3.5 \mathrm{~Hz}, \mathrm{H}-2)$ and between $\mathrm{H}-2$ and the methylene protons $\mathrm{H}-3$ at $\delta_{\mathrm{H}} 1.81(\mathrm{dd}, J=14.5,7.8 \mathrm{~Hz})$, and $1.91(\mathrm{dd}, J=14.5,0.9 \mathrm{~Hz})$. Furthermore, the HMBC spectrum exhibited correlations between the aldehyde proton H-1 and the carbons C-2 $\left(\delta_{\mathrm{C}}\right.$ $61.5)$ and $\mathrm{C}-3\left(\delta_{\mathrm{C}} 39.1\right)$, and from $\mathrm{C}-3$ to $\mathrm{H}_{3}-23$ and $\mathrm{H}_{3}-24$. These data were similar to zizyberanal acid possessing an aldehyde at C-1 and no oxygenation at C-3 (Guo et al., 2009). The relative configuration of C-2 for 1 was further suggested by the ROESY spectrum, wherein rOe effects were displayed between H2 and the $\beta$-axial methyl $\mathrm{H}-24$ and $\mathrm{H}-25$, indicating the $\beta$-orientation of $\mathrm{H}-2$ and the $\alpha$-orientation of the aldehyde group as in zizyberanal acid (Guo et al., 2009). Thus the structure of compound 1 was deduced as $2 \alpha$-formyl-A(1)norlup-20(29)-en-28-oic acid.

Compound 2 had the same molecular formula $\mathrm{C}_{30} \mathrm{H}_{46} \mathrm{O}_{3}$ as 1 [HRESIMS: $m / z$ 477.3329 [M+Na] ${ }^{+}$, calcd for $\left.\mathrm{C}_{30} \mathrm{H}_{46} \mathrm{O}_{3} \mathrm{Na}, 477.3345\right]$. The ${ }^{1} \mathrm{H}$ NMR and ${ }^{13} \mathrm{C}$ NMR spectra of 2 showed signals very similar to those of compound 1. The differences lay in the coupling constants and chemical shifts of signals on the ring A suggesting another stereochemistry for the aldehyde group (Table 1). The relative configuration of C-2 for 2 was deduced from rOe effect between $\mathrm{H}-1\left(\delta_{\mathrm{H}} 9.73(\mathrm{~d}, J=4.7 \mathrm{~Hz})\right)$, and $\mathrm{H}-25$, indicating the $\beta$ orientation of H-1 as in zizyberanalic acid (Kundu et al., 1989). Full assignments of the proton and carbon resonances of compound 2 were achieved by analysis of the COSY, $J$-modulated HSQC and HMBC spectra. Thus compound 2 is $2 \beta$-formyl-A(1)norlup-20(29)-en-28-oic acid.

Compound 3 had the molecular formula $\mathrm{C}_{54} \mathrm{H}_{86} \mathrm{O}_{25}$ deduced from the positive HRESIMS spectrum $[\mathrm{m} / \mathrm{z}$ $1157,5349[\mathrm{M}+\mathrm{Na}]^{+}$, calcd for $\left.\mathrm{C}_{54} \mathrm{H}_{86} \mathrm{O}_{25} \mathrm{Na}, 1157,5356\right]$. The ${ }^{1} \mathrm{H}$ NMR spectrum of the aglycone of 3 
showed signals of a lupane triterpenoid characterized by six tertiary methyl groups $\left(\delta_{\mathrm{H}} 0.94,1.01,1.02\right.$, $1.09,1.10$ and 1.71), an exomethylene group $\left(\delta_{\mathrm{H}} 4.61\right.$ and 4.73 , each $\left.\mathrm{brs}\right)$, and an oxymethine $\left(\delta_{\mathrm{H}} 4.10\right.$, brs $)$. Its ${ }^{13} \mathrm{C}$ NMR spectrum exhibited 30 carbon signals including two carboxyl groups $\left(\delta_{\mathrm{C}} 174.5\right.$ and 177.4), an exomethylene $\left(\delta_{\mathrm{C}} 108.8\right.$ and 150.4$)$, and an oxymethine $\left(\delta_{\mathrm{C}} 84.5\right)$ (Table 2$)$. Analysis of the COSY, $J$-modulated HSQC and HMBC spectra and comparison of these data with the literature revealed that the aglycone was ceanothic acid (Jou et al., 2004). The shielded chemical shift of C-28 suggested a monodesmosidic saponin. Analysis of the ${ }^{1} \mathrm{H}$ and ${ }^{13} \mathrm{C}$ NMR spectra of 3 revealed the presence of four anomeric protons at $\delta_{\mathrm{H}} 5.62(\mathrm{~d}, J=7.9 \mathrm{~Hz}), 5.04(\mathrm{~d}, J=7.4 \mathrm{~Hz}), 4.73(\mathrm{~d}, J=7.8 \mathrm{~Hz})$, and $4.59(\mathrm{~d}, J=7.8 \mathrm{~Hz})$ correlated in the $J$-modulated HSQC spectrum with anomeric carbons at $\delta_{\mathrm{C}} 92.0$, 101.2, 103.4 and 103.4, respectively (Table 2). Analysis of the COSY, TOCSY and $J$-modulated HSQC spectra of $\mathbf{2}$ allowed complete assignment of the four glycosidic proton and carbon systems leading to five $\beta$-D-glucopyranose units (Agrawal, 1992) (Table 2). The anomeric configurations were confirmed by the rOe effects observed between the $\alpha$-axial protons $\mathrm{H}-1 / \mathrm{H}-3$ and $\mathrm{H}-1 / \mathrm{H}-5$ in each sugar unit. The three anomeric carbons at $\delta_{\mathrm{C}} 101.2$ and 103.4 indicated that these carbons were involved in ether linkages while the anomeric carbon at $\delta_{\mathrm{C}} 92.0\left(\delta_{\mathrm{H}} 5.62\right)$ is linked by an ester bond. This was confirmed by the HMBC correlations between Glc-H-1' $(\delta 5.62)$ and C-28 $(\delta$ 174.5). Other HMBC correlations between Glc-H-1" ( $\delta$ 5.04) and Glc-C-2' ( $\delta 76.4)$, Glc-H-1"' ( $\delta 4.73)$ and Glc-C-2" ( $\delta 81.2)$, and Glc-H1 "' $(\delta 4.59)$ and Glc-C-3" ( $\delta$ 86.2) revealed the sequence of the tetrasaccharide moiety with the second glucose unit disubstituted in positions C-2" and C-3". These data compared to the pentaglucoside ceanothic acid, 28- $O$ - $\beta$-D-glucopyranosyl- $(1 \rightarrow 6)$-[ $\beta$-D-glucopyranosyl-( $1 \rightarrow 3)]$-[ $\beta$-D-glucopyranosyl$(1 \rightarrow 2)]-\beta$-D-glucopyranosyl-( $1 \rightarrow 2)-\beta$-D-glucopyranosylceanothic acid, isolated from the leaves (Muhammad et al., 2016), showed the loss of a glucopyranosyl moiety at C-6" of the second glucose unit in $\mathbf{3}$. Thus the structure of saponin 3 was deduced as $28-O-\beta$-D-glucopyranosyl- $(1 \rightarrow 3)-[\beta$-Dglucopyranosyl-( $1 \rightarrow 2)$ ]- $\beta$-D-glucopyranosyl-(1 $\rightarrow 2)-\beta$-D-glucopyranosylceanothic acid.

Comparison of the ${ }^{1} \mathrm{H}$ NMR and ${ }^{13} \mathrm{C}$ NMR spectra of compounds $4-8$ with compound 9 indicated that they all possess the same genin (9), 17,20-didehydro-20-deoxyjujubogenin, glycosylated at C-3 $\left(\delta_{\mathrm{C}} 88.2\right)$ (Pawar et al., 2007) (Table 3). The ${ }^{1} \mathrm{H}$ - and ${ }^{13} \mathrm{C}-\mathrm{NMR}$ spectra of 9 were similar to those of the aglycone of bacoside $\mathrm{A}_{6}$, a saponin from Bacopa monnieri (Pawar et al., 2007). The ${ }^{1} \mathrm{H}$ NMR spectrum of the aglycone 9 showed signals of a dammarane triterpenoid, characterized by seven tertiary methyl groups $\left(\delta_{\mathrm{H}} 0.80,0.90,0.99,1.13,1.67,1.72\right.$ and 1.76$)$, a vinyl proton $\left(\delta_{\mathrm{H}} 5.19, d t, J=8.4,1.4 \mathrm{~Hz}\right)$, two oxygenbearing methines $\left[\delta_{\mathrm{H}} 3.15(d d, J=11.4,5.0 \mathrm{~Hz}), 4.71(d d d, J=11.5,7.9,3.4 \mathrm{~Hz})\right]$, and an oxygen-bearing methylene group $\left[\delta_{\mathrm{H}} 4.08(\mathrm{brs})\right]$. Its ${ }^{13} \mathrm{C}$ NMR and $J$-modulated HSQC spectra exhibited signals for seven 
methyl groups [ $\delta_{\mathrm{C}} 14.7(\mathrm{C}-29), 15.2(\mathrm{C}-19), 16.2(\mathrm{C}-21), 17.0(\mathrm{C}-27), 17.8(\mathrm{C}-30), 24.4(\mathrm{C}-26)$, and 27.2 $(\mathrm{C}-28)]$, two oxymethine carbons $\left[\delta_{\mathrm{C}} 78.0(\mathrm{C}-3)\right.$ and $\left.69.0(\mathrm{C}-23)\right]$, four olefinic carbons $\left[\delta_{\mathrm{C}} 124.1(\mathrm{C}-20)\right.$, $124.4(\mathrm{C}-24), 133.6(\mathrm{C}-17)$, and 135.5 (C-25)], an oxymethylene carbon [ $\delta_{\mathrm{C}} 66.1(\mathrm{C}-18)$ ], and an acetal carbon $\left[\delta_{\mathrm{C}} 106.8(\mathrm{C}-16)\right]$ (Table 3$)$. The shielded nature of C-3 $\left(\delta_{\mathrm{C}} 78.0\right)$ suggested a free hydroxyl at the C-3 position. Analysis of the COSY, J-modulated HSQC and HMBC spectra confirmed its identity as 17,20-didehydro-20-deoxyjujubogenin (Pawar et al., 2007). This is the first report of the isolation of this aglycone though three of its saponins, including bacoside $\mathrm{A}_{6}$, have recently been identified in an extract of Bacopa monnieri (Nuengchamong et al, 2016).

Compound 4 had the molecular formula $\mathrm{C}_{41} \mathrm{H}_{64} \mathrm{O}_{12}$ [HRESIMS: $m / z 771.4286[\mathrm{M}+\mathrm{Na}]^{+}$, calcd for $\left.\mathrm{C}_{41} \mathrm{H}_{64} \mathrm{O}_{12} \mathrm{Na}, 771.4295\right]$. The ${ }^{1} \mathrm{H}$ and ${ }^{13} \mathrm{C}$ NMR spectra of $\mathbf{4}$ showed supplementary signals assignable to the sugar units with their anomeric protons at $\delta_{\mathrm{H}} 4.30(\mathrm{~d}, J=7.4 \mathrm{~Hz})$, and $4.57(\mathrm{~d}, J=7.7 \mathrm{~Hz})(\mathrm{Table} 4)$ correlated in the $J$-modulated HSQC spectrum with anomeric carbons at $\delta_{\mathrm{C}} 105.7$, and 104.0, respectively (Table 5). Analysis of the COSY and $J$-modulated HSQC spectra of 4 allowed complete assignment of proton and carbon systems of a pentose and a hexose, identified as a terminal $\beta$-Dglucopyranose $\left(\delta_{\mathrm{H}} 4.57\right)$ and an $\alpha$-L-arabinopyranose characterized by its equatorial proton $\mathrm{H}-4\left(J_{\mathrm{H}-3^{\prime}-\mathrm{H}-4^{\prime}}\right.$ $=3.3 \mathrm{~Hz}$ ) substituted on the hydroxyl at C-3' ( $\left.\delta_{\mathrm{C}} 82.4\right)$ (Agrawal, 1992) (Tables 4 and 5). The HMBC correlations between Glc-H-1" ( $\delta$ 4.57)/Ara-C-3', Ara-H-1' $(\delta 4.30) / C-3$ ( $\delta 89.1)$, and the rOe correlations between Glc-H-1"/Ara-H-3', Ara-H-1'/H-3 revealed the linkage of the disaccharide moiety. Thus, the structure of saponin 4 was identified as 3-O- $\beta$-D-glucopyranosyl- $(1 \rightarrow 3)-\alpha-\mathrm{L}-$ arabinopyranosyl-17,20-didehydro-20-deoxyjujubogenin (Fig. 1).

The positive HRESIMS spectrum of compound 5 exhibited two pseudomolecular ions at $\mathrm{m} / \mathrm{z} 895.5056$ $[\mathrm{M}+\mathrm{H}]^{+}$and $m / z, 917.5215[\mathrm{M}+\mathrm{Na}]^{+}$, corresponding to a molecular formula $\mathrm{C}_{47} \mathrm{H}_{74} \mathrm{O}_{16}$, and 146 additional molecular weight units relative to $\mathbf{4}$, suggesting the presence of an additional deoxyhexose unit. Three anomeric signals were observed in ${ }^{1} \mathrm{H}-\mathrm{NMR}$ and ${ }^{13} \mathrm{C}-\mathrm{NMR}$ spectra at $\delta_{\mathrm{H}} 5.24(\mathrm{~d}, J=1.5 \mathrm{~Hz}$, $\left.\delta_{\mathrm{C}} 100.6\right), 4.52\left(\mathrm{~d}, J=7.7 \mathrm{~Hz}, \delta_{\mathrm{C}} 106.8\right)$, and 4.51 (d, $\left.J=7.7 \mathrm{~Hz}, \delta_{\mathrm{C}} 102.9\right)$ (Tables 4 and 5 ). Analysis of COSY, $J$-modulated HSQC, and HMBC experiments identified the three sugars moieties as in $\mathbf{1 3}$ (Muhammad et al., 2016), a terminal $\beta$-D-glucopyranose ( $\left.\delta_{\mathrm{H}} 4.51\right)$, a terminal $\alpha$-L-rhamnopyranose $\left(\delta_{\mathrm{H}}\right.$ 5.24) with its methyl signal at $\delta_{\mathrm{H}} 1.24(\mathrm{~d}, J=6.2 \mathrm{~Hz})$ and $\delta_{\mathrm{C}} 16.8$, and an $\alpha$-L-arabinopyranose $\left(\delta_{\mathrm{H}} 4.52\right)$ disubstituted at positions C-2' $\left(\delta_{\mathrm{C}} 73.9\right)$ and C-3' $\left(\delta_{\mathrm{C}}\right.$ 80.9) (Agrawal, 1992) (Tables 4 and 5). The interglycosidic linkage was confirmed by the HMBC correlations observed between Glc-H-1'"/Ara-C-3', Rha-H-1"/Ara-C-2', and Ara-H-1'/C-3. Thus, the structure of compound 5 is the previously undescribed 
3-O- $\beta$-D-glucopyranosyl-( $1 \rightarrow 3)$-[ $\alpha$-L-rhamnopyranosyl- $(1 \rightarrow 2)]-\alpha$-L-arabinopyranosyl-17,20-didehydro20-deoxyjujubogenin (Fig. 1).

Compound 6 had the molecular formula $\mathrm{C}_{53} \mathrm{H}_{84} \mathrm{O}_{21}$ [HRESIMS: $\mathrm{m} / z 1079.5399[\mathrm{M}+\mathrm{Na}]^{+}$, calcd for $\left.\mathrm{C}_{53} \mathrm{H}_{84} \mathrm{O}_{21} \mathrm{Na}, 1079.5403\right]$. The ${ }^{1} \mathrm{H}$ and ${ }^{13} \mathrm{C}$ NMR spectra and MS data of $\mathbf{6}$ showed an additional sugar unit, relative to 5, identified as a hexose unit with its anomeric proton at $\delta_{\mathrm{H}} 4.77(\mathrm{~d}, J=7.4 \mathrm{~Hz}$ ) (Table 4), and anomeric carbon at $\delta_{\mathrm{C}} 102.0$ (Table 5). Analysis of COSY, TOCSY, $J$-modulated HSQC, and HMBC allowed assignment of two $\beta$-D-glucopyranoses, one terminal $\left(\delta_{\mathrm{H}} 4.77\right)$ and one substituted at position C-2"' ( $\left.\delta_{\mathrm{C}} 76.5\right)$, a terminal $\alpha$-L-rhamnopyranose $\left(\delta_{\mathrm{H}} 5.20\right)$, and an $\alpha$-L-arabinopyranose $\left(\delta_{\mathrm{H}} 4.39\right)$ disubstituted at positions C-2' $\left(\delta_{\mathrm{C}} 73.9\right)$ and C-3' $\left(\delta_{\mathrm{C}} 81.7\right)$ (Agrawal, 1992) (Tables 4 and 5$)$ as in 15 (Muhammad et al., 2016). The interglycosidic linkages were identical to those observed in saponin $\mathbf{1 5}$ with HMBC correlations between Glc-H-1'"'/Glc-C-2"', Glc-H-1"'/Ara-C-3', Rha-H-1"/Ara-C-2', and Ara-H-1'/C-3. Thus, compound 6 was identified as 3-O- $\beta$-D-glucopyranosyl-(1 $\rightarrow 2)-\beta$-D-glucopyranosyl$(1 \rightarrow 3)$-[ $\alpha$-L-rhamnopyranosyl-( $(1 \rightarrow 2)]-\alpha$-L-arabinopyranosyl-17,20-didehydro-20-deoxyjujubogenin (Fig. 1).

Compounds 7 and 8 had the same molecular formula $\mathrm{C}_{53} \mathrm{H}_{84} \mathrm{O}_{21}$, [HRESIMS: $m / z 1079.5399$ [M+Na] ${ }^{+}$, calcd for $\mathrm{C}_{53} \mathrm{H}_{84} \mathrm{O}_{21} \mathrm{Na}, 1079.5403$ ] and contained 132 additional molecular weight units relative to 6 , suggesting the presence of an additional pentose unit. The ${ }^{1} \mathrm{H}$ - and ${ }^{13} \mathrm{C}-\mathrm{NMR}$ spectra of the sugar part of compounds 7 and $\mathbf{8}$ were very similar to those of $\mathbf{1 6}$ and 17 (Muhammad et al., 2016). Five anomeric signals were observed in ${ }^{1} \mathrm{H}-\mathrm{NMR}$ and ${ }^{13} \mathrm{C}-\mathrm{NMR}$ spectra at $\delta_{\mathrm{H}} 4.34\left(d, J=7.5 \mathrm{~Hz}, \delta_{\mathrm{C}} 104.3\right), 4.40(d, J$ $\left.=6.5 \mathrm{~Hz}, \delta_{\mathrm{C}} 104.7\right), 4.70\left(d, J=7.5 \mathrm{~Hz}, \delta_{\mathrm{C}} 101.6\right), 4.89\left(d, J=7.3 \mathrm{~Hz}, \delta_{\mathrm{C}} 102.7\right)$ and $5.27\left(d, J=1.5 \mathrm{~Hz}, \delta_{\mathrm{C}}\right.$ $100.8)$ for compound 7 and at $\delta_{\mathrm{H}} 4.36\left(d, J=6.8 \mathrm{~Hz}, \delta_{\mathrm{C}} 104.1\right), 4.40\left(d, J=6.5 \mathrm{~Hz}, \delta_{\mathrm{C}} 104.7\right), 4.70(d, J$ $\left.=7.5 \mathrm{~Hz}, \delta_{\mathrm{C}} 101.6\right), 4.88\left(d, J=7.3 \mathrm{~Hz}, \delta_{\mathrm{C}} 102.6\right)$ and $5.31\left(d, J=1.3 \mathrm{~Hz}, \delta_{\mathrm{C}} 100.6\right)$ for compound 8 (Tables 4 and 5). Analysis of COSY, TOCSY, $J$-modulated HSQC, and HMBC experiments identified the four sugars moieties as in $\mathbf{6}$ and the supplementary pentose unit was identified as a $\beta$-D-xylopyranose in compound $\mathbf{7}$ and an $\alpha$-L-arabinopyranose in $\mathbf{8}$ (Agrawal, 1992), as in compounds $\mathbf{1 6}$ and 17, respectively (Muhammad et al., 2016). These sugars were attached to the $\beta$-D-glucopyranose at C-6"'" as suggested by its deshielded signal ( $\left.\delta_{\mathrm{C}} 68.1\right)$ (Table 5). The HMBC correlations were observed between Xyl-H-1"'"/Glc-C-6"'", Glc-H-1'"'/Glc-C-2"', Glc-H-1"'/Ara-C-3', Rha-H-1"/Ara-C-2', and Ara-H-1'/C-3 for compound 7 and between Ara-H-1"'"/Glc-C-6'"', Glc-H-1'"'/Glc-C-2"', Glc-H-1"'/Ara-C-3', Rha-H1"/Ara-C-2', and Ara-H-1'/C-3 for compound 8. Thus, the structure of compound 7 is the previously undescribed 3- $O$ - $\beta$-D-xylopyranosyl- $(1 \rightarrow 6)-\beta$-D-glucopyranosyl-( $1 \rightarrow 2)-\beta$-D-glucopyranosyl- $(1 \rightarrow 3)-[\alpha$ L-rhamnopyranosyl-(1 $\rightarrow 2)$ ]- $\alpha$-L-arabinopyranosyl-17,20-didehydro-20-deoxyjujubogenin, and compound $\mathbf{8}$ is the previously undescribed 3- $O$ - $\alpha$-L-arabinopyranosyl-( $1 \rightarrow 6)-\beta$-D-glucopyranosyl- 
$(1 \rightarrow 2)$ - $\beta$-D-glucopyranosyl-( $1 \rightarrow 3)$-[ $\alpha$-L-rhamnopyranosyl-( $1 \rightarrow 2)]-\alpha$-L-arabinopyranosyl-17,20didehydro-20-deoxyjujubogenin (Fig. 1).

The antioxidant activity of the EtOAc and hydromethanolic extracts at $200 \mu \mathrm{g} / \mathrm{mL}$ of the stem and bark was $18.5 \%, 22.6 \%, 78.5 \%$ and $82.5 \%$, respectively. The hydromethanolic extracts were the most active with both an $\mathrm{EC}_{50}=73 \mu \mathrm{g} / \mathrm{mL}$ for the DPPH radical scavenging activity. This activity is low considering the presence of rutin $(\mathbf{1 8})\left(\mathrm{EC}_{50}=15.3 \mu \mathrm{g} / \mathrm{mL}\right.$ (Lue et al., 2010), maesopsin $\left(\mathrm{EC}_{50}=5.3\right.$ $\mu \mathrm{g} / \mathrm{mL}$ ) (Krenn et al., 2003) and the phenol glycosides (19-21).

The EtOAc extracts of the stem and bark showed no tyrosinase inhibition whereas the hydromethanolic extracts of the stem and bark showed $29.9 \%$ and $49.6 \%$ inhibition, respectively. The four lupane triterpenoids $(\mathbf{1}, \mathbf{1 0 - 1 2})$ were tested at $4 \mathrm{mg} / \mathrm{mL}$ and their activity was very low with $36.5 \%, 28.4 \%$, $44.8 \%$ and $36.6 \%$ tyrosinase inhibition, respectively.

The cytotoxic activity of the five lupane triterpenoids $(\mathbf{1 - 2}, \mathbf{1 0 - 1 2})$, the ceanothic acid saponin $(3)$, the two dammarane saponins (5-6), the ( \pm ) lyoniresinol derivative (22), and the maesopsin derivative (23), against a KB cell line, was measured using a WST-1 proliferation test. The three saponins tested $(\mathbf{3}, \mathbf{5 - 6}),( \pm)-3 \alpha-$ $O$ - $\beta$-D-glucopyranosyl-lyonirésinol (22), and ( \pm )-4- $O$ - $\beta$-D-glucopyranosyl-maesopsin (23) showed very low cytotoxic activity with growth inhibitions ranging from 2.5 to $13.0 \%$ at $10 \mu \mathrm{g} / \mathrm{mL}$ (See supplementary Information for details). Ceanothic acid (10) showed a moderate activity with growth inhibitions of $30.8 \%$. The four lupane triterpenoids $(\mathbf{1}, \mathbf{2}, \mathbf{1 1}, \mathbf{1 2})$ were the most active with growth inhibitions of $72.9 \%, 77.0$ $\%, 79.5 \%$ and $79.3 \%$, respectively, and $\mathrm{IC}_{50}$ ranging from 1.2 to $4.0 \mu \mathrm{g} / \mathrm{mL}$. Ceanothenic acid (11) showed good cytotoxic activity $(2.6 \pm 0.16 \mu \mathrm{M})$ and is more active than alphitolic acid (12) $(8.5 \pm 0.25$ $\mu \mathrm{M})$, and the two previously undescribed compounds $\mathbf{1}$ and $\mathbf{2}$, with $\mathrm{IC}_{50}$ values of $7.9 \pm 0.12 \mu \mathrm{M}$ and 7.0 $\pm 0.17 \mu \mathrm{M}$, respectively. By comparison of these data, the stereochemistry of the aldehyde group did not affect the activity between $\mathbf{1}$ and $\mathbf{2}$.

The disk diffusion method was used to evaluate the possible antimicrobial activity of the five lupane triterpenes $(\mathbf{1 - 2}, \mathbf{1 0 - 1 2})$, the ceanothic acid saponin $(\mathbf{3})$, the dammarane saponin $(\mathbf{5}),( \pm) 3 \alpha-O-\beta$-Dglucopyranosyl-lyonirésinol (22), and ( \pm ) 4-O- $\beta$-D-glucopyranosyl-maesopsin (23), against four bacteria including two Gram positive (S. aureus and E. faecalis) and two Gram negative (E. coli and $P$. aeruginosa). Only ceanothenic acid (11) and $2 \alpha$-formyle-A(1)norlup-20(29)-en-28-oic acid (1) showed moderate antibacterial activity with inhibition diameters of 10 and 12 for 1 and 16 and 14 for 11 against $S$. aureus and E. faecalis, respectively. No inhibition zone was observed with $2 \beta$-formyl-A(1)norlup20(29)-en-28-oic acid (2), nor any activity on gram negative bacteria, at the concentrations tested. To further characterize the antibacterial activities of compounds $\mathbf{1}$ and $\mathbf{1 1}$ their MIC values against $S$. aureus and E. faecalis were also determined using the microdilution method (Muhammad et al., 2016). 
Compound 1 showed good antibacterial activity with MIC values of $4 \mu \mathrm{g} / \mathrm{mL}$ against both $S$. aureus and E. faecalis, and compound $\mathbf{1 1}$ has a moderate activity with MIC values of 8 and $16 \mu \mathrm{g} / \mathrm{mL}$ against $S$. aureus and E. faecalis, respectively (See supplementary Information for details).

In conclusion, twenty four compounds, including eight previously undescribed structures, were isolated from the stems and bark of J. xerocarpa. The free 17,20-didehydro-20-deoxyjujubogenin (9) and its five glycosides (4-8), as well as the two lupane derivatives, the $2 \alpha / \beta$-formyl-A(1)norlup-20(29)-en-28-oic acid (1-2) are described for the first time in Jaffrea species. Two compounds, zizyberanal and zizyberanalic acid, possessing an aldehyde group at position 1, were isolated from another Rhamnaceae species, Zizyphus jujuba (Guo et al., 2009). Rutin (18), a common flavonoid, and saponins 13-17 were previously isolated from the leaves of A. xerocarpus (= J. xerocarpa) (Muhammad et al., 2016). Ceanothic acid (10), ceanothenic acid (11) and alphitolic acid (12) are common in Alphitonia species and the Rhamnaceae and can be considered as chemotaxonomic markers. This is the first identification in Jaffrea species that confirmed the similarity of Alphitonia and Jaffrea species. The three phenol glycosides (19-21) were isolated for the first time from the Rhamnaceae family. The hydromethanolic extract showed antioxidant activity (DPPH essay) due to the presence of phenols. Three lupane triterpenes $(\mathbf{1}, \mathbf{2}, \mathbf{1 2})$, showed a good cytotoxic activity against a $\mathrm{KB}$ cell line ( $\mathrm{IC}_{50}$ ranging from 7.0 to $8.5 \mu \mathrm{M}$ ) but were less active than ceanothenic acid (11) ( $\mathrm{IC}_{50} 2.6 \mu \mathrm{M}$ ). The previously undescribed $2 \alpha$-formyl-A(1)norlup-20(29)-en-28oic acid (1) is the major compound of both the AcOEt and hydromethanolic extracts and showed good antibacterial activity against $S$. aureus and E. faecalis (MIC $4 \mu \mathrm{g} / \mathrm{mL}$ ).

\section{Experimental}

\subsection{General experimental procedures}

Optical rotations were determined in $\mathrm{MeOH}$ with a Perkin-Elmer 341 polarimeter. ${ }^{1} \mathrm{H}$ and ${ }^{13} \mathrm{C} \mathrm{NMR}$ spectra were recorded on a Bruker Avance III 500 spectrometer $\left({ }^{1} \mathrm{H}\right.$ at $500 \mathrm{MHz}$ and ${ }^{13} \mathrm{C}$ at $\left.125 \mathrm{MHz}\right)$ or on a Bruker Avance III 600 spectrometer equipped with a cryoprobe $\left({ }^{1} \mathrm{H}\right.$ at $600 \mathrm{MHz}$ and ${ }^{13} \mathrm{C}$ at 150 MHz). 2D-NMR experiments were performed using standard Bruker microprograms. Chemical shift $(\delta)$ were reported in ppm using the internal solvent resonances at $\delta_{\mathrm{H}} 3.33$ and $\delta_{\mathrm{C}} 47.6\left(\mathrm{CD}_{3} \mathrm{OD}\right)$. HRESIMS experiments were performed using a hybrid quadrupole/time-of-flight (Q-TOF) instrument, equipped with a pneumatically assisted electrospray ion source operated in positive ionization mode (Micromass, Manchester, UK). The samples were introduced by direct infusion in a solution of $\mathrm{MeOH}$ at a flow rate 
of $5 \mu \mathrm{L} / \mathrm{min}$. The spray capillary voltage was set at $3500 \mathrm{~V}$, and the extraction cone voltage between 30 $60 \mathrm{~V}$. The source temperature was $80^{\circ} \mathrm{C}$ and the desolvatation temperature was $100^{\circ} \mathrm{C}$.

Analytical TLC were carried out on precoated silica gel $60 \mathrm{~F}_{254}$ plates (Merck, Darmstadt, Germany). Spots were visualized after spraying with $50 \% \mathrm{H}_{2} \mathrm{SO}_{4}$ and heating at $100{ }^{\circ} \mathrm{C}$ for $1 \mathrm{~min}$. $\mathrm{CC}$ was carried out on Kieselgel 60 (63-200 mesh), or LiChroprep RP-18 (40-63 $\mu \mathrm{m})$ Merck. Flash chromatography was performed on a $\mathrm{C}_{18}$ reversed phase (Reveleris $\mathrm{C}_{18}$ reversed phase $40 \mathrm{~g}$; $\mathrm{CV} 45 \mathrm{~mL} / \mathrm{min} ; 45 \mathrm{mg}-1.35$ g sample) or on silica gel 60 (Reveleris silica $40 \mu \mathrm{m}, 12 \mathrm{~g}$; CV 17-36 mL/min; 45 mg-2.4 g sample, or Reveleris silica $40 \mu \mathrm{m}, 4 \mathrm{~g}$; CV 5-18 mL/min; 4 mg-800 mg sample) columns. Analytical and semipreparative HPLC were performed on a Dionex apparatus equipped with an ASI-100 automated sample injector, a STH 585 column oven, a P580 pump, a diode array detector UVD 340S and the Chromeleon ${ }^{\circledR}$ software version 6.8. Analytical HPLC separations were performed on a prepacked $\mathrm{C}_{18}$ reversed phase column Luna ( 250 x $4.6 \mathrm{~mm}, 5 \mu \mathrm{m}$, Phenomenex, France). Semi-preparative HPLC separations were performed on a prepacked $\mathrm{C}_{18}$ reversed phase column Luna $(250 \mathrm{x} 10 \mathrm{~mm}, 5 \mu \mathrm{m}$, Phenomenex, France). The chromatograms were monitored at 205, 210, 254 and $312 \mathrm{~nm}$.

96-well microplates Greiner ${ }^{\circledR}$ F Bottom (BMG-LABTECH, Champigny sur Marne, France) and a BMG-LABTECH UV-Vis Spectrophotometer Micro-plate reader FLUOstar Omega were used for absorbance measurements in biological assays. DPPH, mushroom tyrosinase (EC 1.14.18.1), L-DOPA, kojic acid (purity 99\%), ascorbic acid, and $\alpha$-hederin were purchased from Sigma-Aldrich. WST-1 was obtained from Roche and DMEM F12 was purchased from Gibco-Invitrogen. The KB cell line DSMZ ACC136 was purchased from Interchim ${ }^{\circledR}$. Deionised water was used to prepare all aqueous solutions.

\subsection{Plant material}

Jaffrea erubescens (Baill.) H. C. Hopkins \& Pillon (Basionym Alphitonia xerocarpus Baill.) stems and bark (Rhamnaceae) were collected by Pr. Mohammed Nour in September 2009 at the end of the cool season in southern province (GPS: $\left.22^{\circ} 10^{\prime} 14,5^{\prime \prime} \mathrm{S} ; 166^{\circ} 45^{\prime} 32,66^{\prime \prime}\right)$. The botanical identification was made at the Laboratoire Insulaire du Vivant et de l'Environnement of the New Caledonia University. A voucher specimen (09NM002) was deposited in the Herbarium of Noumea (New Caledonia).

\subsection{Extraction and isolation}

Powdered air-dried stems of J. xerocarpa $(200 \mathrm{~g})$ were macerated overnight in $4.0 \mathrm{~L}$ of petroleum ether and lixiviated to give $1.6 \mathrm{~g}$ of petroleum ether extract after evaporation. The defatted powdered material was then macerated overnight and lixiviated with $4.0 \mathrm{~L}$ of EtOAc to afford after evaporation of the solvent $3.8 \mathrm{~g}$ of EtOAc extract. After drying, the resulting powdered material was reflux for $3 \mathrm{~h}$ with 
$\mathrm{MeOH}-\mathrm{H}_{2} \mathrm{O}(8: 2)(2.0 \mathrm{~L})$, and then dried under reduced pressure to yield $33.4 \mathrm{~g}$ of a hydromethanolic extract.

The EtOAc extract $(3.8 \mathrm{~g}$ ) was purified by silica gel flash chromatography using a gradient of $n$ cyclohexane- $\mathrm{CHCl}_{3}$ (from 8:2 to 0:1) during $30 \mathrm{~min}$, and then $\mathrm{CHCl}_{3}$-EtOAc (from 1:0 to 0:1) during 30 min, to afford 206 fractions. Fractions [1-29] (118 mg) eluted with $n$-cyclohexane- $\mathrm{CHCl}_{3}$ were purified by silica gel flash chromatography using a gradient of $n$-cyclohexane- $\mathrm{CHCl}_{3}$ (from 1:0 to 6:4) during 20 min with a flow rate of $12 \mathrm{~mL} / \mathrm{min}$, to afford compound 1 (53.3 mg). Fractions [92-97] (121.8 mg) eluted with $\mathrm{CHCl}_{3}$-EtOAc were purified by silica gel flash chromatography using a gradient of tolueneEtOAc (from 1:0 to 7:3) during $35 \mathrm{~min}$ with a flow rate of $15 \mathrm{~mL} / \mathrm{min}$. The resulting fractions [23-30] (121.8 mg) eluted with toluene- EtOAc (8:2) were purified by silica gel flash chromatography using a gradient of toluene-EtOAc (from 1:0 to 85:15) during $30 \mathrm{~min}$ with a flow rate of $15 \mathrm{~mL} / \mathrm{min}$, to afford compound 12 (6.9 mg) in fractions [26-27]. The resulting fractions [20-23] eluted with toluene-EtOAc (85:15) were purified by silica gel flash chromatography using a gradient of toluene-EtOAc (from 1:0 to 93:7) during $30 \mathrm{~min}$ with a flow rate of $15 \mathrm{~mL} / \mathrm{min}$, to give compounds $\mathbf{1 2}(3.3 \mathrm{mg})$ and $\mathbf{1 0}(3.3 \mathrm{mg})$. Fractions [135-149] (680 mg), eluted with 100\% EtOAc, were purified by silica gel flash chromatography using a gradient of $\mathrm{CHCl}_{3}-\mathrm{MeOH}$ (from 1:0 to 85:15) during 20 min, to afford compound 11 (6.2 mg) in fractions [36-40].

Powdered air-dried bark of J. xerocarpa (500 g) was reflux for $3 \mathrm{~h}$ with $\mathrm{MeOH}-\mathrm{H}_{2} \mathrm{O}(8: 2)$ (5 L), and then filtered and dried under reduced pressure to yield $85 \mathrm{~g}$ of a hydromethanolic extract. A part of the hydromethanolic extract ( $80 \mathrm{~g}$ ) was subjected to vacuum liquid chromatography on silica gel, eluted successively with $1 \mathrm{~L}$ of $\mathrm{CHCl}_{3}-\mathrm{MeOH}(1: 0,72: 25,5: 5,25: 75$ and $0: 1)$, to give fractions I (3.2 g), II (13.5 g), III (23.7 g), IV (15.6 g), and V (8.9 g), respectively.

Fraction I ( $3 \mathrm{~g}$ ) was purified by silica gel flash chromatography using a gradient of $n$-cyclohexane$\mathrm{CHCl}_{3}$ (from 8:2 to 0:1) during 20 min with a flow rate of $35 \mathrm{~mL} / \mathrm{min}$, and then $\mathrm{CHCl}_{3}$-EtOAc (from 1:0 to $0: 1)$ during $15 \mathrm{~min}$, to afford 70 fractions. Fractions [9-12] (103.8 mg) eluted with $n$-cyclohexane$\mathrm{CHCl}_{3}$ were purified by silica gel flash chromatography using a gradient of $n$-cyclohexane- $\mathrm{CHCl}_{3}$ (from 9:1 to 6:4) during $40 \mathrm{~min}$ with a flow rate of $13 \mathrm{~mL} / \mathrm{min}$, to afford compounds 1 (57.9 $\mathrm{mg}$ ) in fractions [13-18] and 2 (4.3 mg) in fractions [21-22]. Compound 10 (59 mg) was obtained by precipitation of fraction [49], eluted with 100\% EtOAc, in the mixture of $\mathrm{CHCl}_{3}-\mathrm{MeOH}(95: 5)$.

Fraction II (13.5 g) was subjected to vacuum liquid chromatography on silica gel, eluted successively with $1 \mathrm{~L}$ of $\mathrm{CHCl}_{3}-\mathrm{MeOH}$ (1:0, 9:1, 8:2, 5:5 and 0:1), to give fractions II-1 (1.3 g), II-2, (2.8 g), II-3 (3.2 g), II-4 (3.1 g), and II-5 (0.6 g), respectively. Fraction II-3 (3 g) was purified by silica gel column chromatography using a gradient of $\mathrm{CHCl}_{3}-\mathrm{MeOH}$ (from 1:0 to 75:25). Fractions [44-49] (834 mg), 
eluted with $\mathrm{CHCl}_{3}-\mathrm{MeOH}$ (85:15), were purified by RP-18 column chromatography using a gradient of $\mathrm{MeOH}-\mathrm{H}_{2} \mathrm{O}$ (from 1:9 to 5:5) to give compounds $19(6.6 \mathrm{mg}), 22(236 \mathrm{mg}$ ), and 24 (5.5 mg). Fractions [53-62] (530 mg), eluted with $\mathrm{CHCl}_{3}-\mathrm{MeOH}$ (8:2), were purified by RP-18 column chromatography using a gradient of $\mathrm{MeOH}-\mathrm{H}_{2} \mathrm{O}$ (from 1:0 to 5:5) to give compounds 20 (2.5 mg), 21 (3.4 mg), 22 (11.4 $\mathrm{mg}$ ), and 23 (25.3 $\mathrm{mg})$.

An aliquot of fraction IV ( $1 \mathrm{~g}$ ) was purified by RP-18 column chromatography using a gradient of $\mathrm{MeOH}-\mathrm{H}_{2} \mathrm{O}$ (from 4:6 to 9:1) to give 65 fractions (15 mL each). Fractions [9-12] (33.4 mg), eluted with $\mathrm{MeOH}-\mathrm{H}_{2} \mathrm{O}$ (4:6), were purified by silica gel column chromatography using the mixture $\mathrm{CHCl}_{3}-\mathrm{MeOH}$ (75:25) to give $10.5 \mathrm{mg}$ of rutin (18). Fractions [21-27] (88.6 mg), eluted with $\mathrm{MeOH}-\mathrm{H}_{2} \mathrm{O}(5: 5)$, contained the pure compound 15. Fractions [40-41] (65 mg), eluted with $\mathrm{MeOH}-\mathrm{H}_{2} \mathrm{O}(6: 4)$, were subjected to semi-prep HPLC on RP-18 eluted with a gradient of $\mathrm{CH}_{3} \mathrm{CN}-\mathrm{H}_{2} \mathrm{O} 0.025 \%$ TFA (1:9 to 5:5) during $15 \mathrm{~min}$ yielding compound 3 (Rt $12.8 \mathrm{~min} ; 8 \mathrm{mg}$ ). Fractions [42-44] (156 mg), eluted with $\mathrm{MeOH}-\mathrm{H}_{2} \mathrm{O}$ (6:4), were subjected to semi-prep HPLC on RP-18 eluted with a gradient of $\mathrm{CH}_{3} \mathrm{CN}-\mathrm{H}_{2} \mathrm{O}$ 0.025\% TFA (45:55 to 6:4) during 10 min yielding compound 14 (Rt $6.8 \mathrm{~min} ; 13 \mathrm{mg}$ ). Fractions [50-52] (99.6 mg), eluted with $\mathrm{MeOH}-\mathrm{H}_{2} \mathrm{O}(7: 3)$ contain the mixture of compounds 16 and $17(6 \mathrm{mg})$ not separable after silica gel column chromatography and semi-prep HPLC on RP-18. A second aliquot of fraction IV ( $2 \mathrm{~g}$ ) was purified by prep- HPLC on RP-18 using a gradient of $\mathrm{MeOH}-\mathrm{H}_{2} \mathrm{O}$ (from 2:8 to $7: 3$ ) at a flow rate of $120 \mathrm{~mL} / \mathrm{min}$, to give 67 fractions (150 mL each). Fractions [32-34] (49 mg), eluted with $\mathrm{MeOH}-\mathrm{H}_{2} \mathrm{O}$ (4:6), were purified by semi-prep HPLC on RP-18 eluted with a gradient of $\mathrm{CH}_{3} \mathrm{CN}$ $\mathrm{H}_{2} \mathrm{O} 0.025 \%$ TFA (18:82 to 22:78) during $10 \mathrm{~min}$ to give rutin (18) (Rt $10.4 \mathrm{~min} ; 8.9 \mathrm{mg}$ ). Fractions [45-48] (271.6 mg), eluted with $\mathrm{MeOH}-\mathrm{H}_{2} \mathrm{O}$ (5:5), were purified by silica gel flash chromatography using a gradient of $\mathrm{CHCl}_{3}-\mathrm{MeOH}$ (from 1:0 to 8:2) during $40 \mathrm{~min}$ at a flow rate of $15 \mathrm{~mL} / \mathrm{min}$. The resulting fractions [80-85] (271.6 mg) were purified by semi-prep HPLC on RP-18 eluted with a gradient of $\mathrm{CH}_{3} \mathrm{CN}-\mathrm{H}_{2} \mathrm{O}$ 0.025\% TFA (45:55 to 6:4) during $15 \mathrm{~min}$ and then (6:4 to 1:0) during $10 \mathrm{~min}$ to give the compounds 15 (Rt $5.4 \mathrm{~min} ; 4.5 \mathrm{mg}), 13(R \mathrm{t} 6.2 \mathrm{~min} ; 6.7 \mathrm{mg}), \mathbf{6}(R \mathrm{t} 12.9 \mathrm{~min} ; 7.0 \mathrm{mg}), 5(R \mathrm{t}$ $15.3 \mathrm{~min} ; 10.0 \mathrm{mg}), 4$ (Rt $18.4 \mathrm{~min} ; 1.3 \mathrm{mg})$, and 9 (Rt $19.8 \mathrm{~min} ; 1.6 \mathrm{mg})$. Fractions [53-55] (156.3 mg), eluted with $\mathrm{MeOH}-\mathrm{H}_{2} \mathrm{O}$ (4:4), were purified by semi-prep HPLC on RP-18 eluted with a gradient of $\mathrm{CH}_{3} \mathrm{CN}-\mathrm{H}_{2} \mathrm{O} 0.025 \%$ TFA (4:6 to 5:5) during $15 \mathrm{~min}$ and then (5:5 to 1:0) during $5 \mathrm{~min}$, to give the compounds 16+17 (Rt $6.5 \mathrm{~min} ; 4.0 \mathrm{mg}), 13$ (Rt $8.3 \mathrm{~min} ; 6.3 \mathrm{mg}), 7$ (Rt $14.9 \mathrm{~min} ; 3.5 \mathrm{mg}$ ), and 8 (Rt 15.2 $\min ; 2.5 \mathrm{mg})$.

\subsection{Compound characterization}

3.4.1. $2 \alpha$-Formyl-A(1)norlup-20(29)-en-28-oic acid (1) 
White amorphous powder; $[\alpha]_{\mathrm{D}}+1.5^{\circ}\left(c 0.83, \mathrm{CHCl}_{3}\right) ;{ }^{1} \mathrm{H} \mathrm{NMR}\left(\mathrm{CDCl}_{3}, 600 \mathrm{MHz}\right)$ and ${ }^{13} \mathrm{C} \mathrm{NMR}$ $\left(\mathrm{CDCl}_{3}, 150 \mathrm{MHz}\right.$ ), see Table 1; HRESIMS (positive-ion mode) $\mathrm{m} / \mathrm{z}: 477.3339[\mathrm{M}+\mathrm{Na}]^{+}($calcd for $\left.\mathrm{C}_{30} \mathrm{H}_{46} \mathrm{O}_{3} \mathrm{Na}, 477.3345\right)$.

\subsection{23-Formyl-A(1)norlup-20(29)-en-28-oic acid (2)}

White amorphous powder; $[\alpha]_{\mathrm{D}}-3.8^{\circ}\left(c 0.26, \mathrm{CHCl}_{3}\right) ;{ }^{1} \mathrm{H} \mathrm{NMR}\left(\mathrm{CDCl}_{3}, 500 \mathrm{MHz}\right)$ and ${ }^{13} \mathrm{C} \mathrm{NMR}$ $\left(\mathrm{CDCl}_{3}, 125 \mathrm{MHz}\right.$ ), see Table 1; HRESIMS (positive-ion mode) $\mathrm{m} / \mathrm{z}: 477.3329[\mathrm{M}+\mathrm{Na}]^{+}$(calcd for $\left.\mathrm{C}_{30} \mathrm{H}_{46} \mathrm{O}_{3} \mathrm{Na}, 477.3345\right)$.

3.4.3. 28-O- $\beta$-D-glucopyranosyl-( $(1 \rightarrow 3)$-[ $\beta$-D-glucopyranosyl- $(1 \rightarrow 2)]-\beta$-D-glucopyranosyl- $(1 \rightarrow 2)-\beta$ - $D$ glucopyranosylceanothic acid (3)

White amorphous powder; $[\alpha]_{\mathrm{D}}+1.7^{\circ}\left(c 0.23, \mathrm{CH}_{3} \mathrm{OH}\right) ;{ }^{1} \mathrm{H} \mathrm{NMR}(\mathrm{MeOD}-\mathrm{d} 4,500 \mathrm{MHz})$ and ${ }^{13} \mathrm{C}$ NMR (MeOD-d4, $125 \mathrm{MHz}$ ), see Table 2 ; HRESIMS (positive-ion mode) $\mathrm{m} / z: 1157.5349[\mathrm{M}+\mathrm{Na}]^{+}$(calcd for $\left.\mathrm{C}_{54} \mathrm{H}_{86} \mathrm{O}_{25} \mathrm{Na}, 1157.5356\right)$.

3.4.4. 3-O- $\beta$-D-glucopyranosyl-( $1 \rightarrow 3$-- $\alpha$-L-arabinopyranosyl-17,20-didehydro-20-deoxyjujubogenin (4) White amorphous powder; $[\alpha]_{\mathrm{D}}+18.0^{\circ}\left(c 0.08, \mathrm{CH}_{3} \mathrm{OH}\right) ;{ }^{1} \mathrm{H}$ NMR $(\mathrm{MeOD}-\mathrm{d} 4,600 \mathrm{MHz})$ and ${ }^{13} \mathrm{C} \mathrm{NMR}$ (MeOD-d4, $150 \mathrm{MHz}$ ) of the aglycone part, see Table 3; ${ }^{1} \mathrm{H}$ NMR (MeOD-d4, $600 \mathrm{MHz}$ ) and ${ }^{13} \mathrm{C}$ NMR (MeOD-d4, $150 \mathrm{MHz}$ ) of the osidic part, see Tables 4 and 5; HRESIMS (positive-ion mode) $\mathrm{m} / \mathrm{z}$ : $771.4286[\mathrm{M}+\mathrm{Na}]^{+}$(calcd for $\left.\mathrm{C}_{41} \mathrm{H}_{64} \mathrm{O}_{12} \mathrm{Na}, 771.4295\right)$.

3.4.5. 3-O- $\beta$-D-glucopyranosyl- $(1 \rightarrow 3)$ - [ $\alpha$-L-rhamnopyranosyl-( $(\rightarrow 2)]-\alpha$-L-arabinopyranosyl-17,20didehydro-20-deoxyjujubogenin (5)

White amorphous powder; $[\alpha]_{\mathrm{D}}-29.7^{\circ}\left(c \mathrm{0.19}, \mathrm{CH}_{3} \mathrm{OH}\right) ;{ }^{1} \mathrm{H} \mathrm{NMR}(\mathrm{MeOD}-\mathrm{d} 4,600 \mathrm{MHz})$ and ${ }^{13} \mathrm{C} \mathrm{NMR}$ (MeOD-d4, $150 \mathrm{MHz}$ ) of the aglycone part is identical to compound $4 \pm 0.2 \mathrm{ppm} ;{ }^{1} \mathrm{H}$ NMR (MeOD-d4, $600 \mathrm{MHz}$ ) and ${ }^{13} \mathrm{C}$ NMR (MeOD-d4, $150 \mathrm{MHz}$ ) of the osidic part, see Tables 4 and 5; HRESIMS (positive-ion mode) $\mathrm{m} / z$ : $917.5215[\mathrm{M}+\mathrm{Na}]^{+}$(calcd for $\mathrm{C}_{47} \mathrm{H}_{74} \mathrm{O}_{16} \mathrm{Na}, 917.4875$ ).

3.4.6. 3-O- $\beta$-D-glucopyranosyl-( $(\rightarrow 2)-\beta$-D-glucopyranosyl- $(1 \rightarrow 3)$-[ $\alpha$-L-rhamnopyranosyl- $(1 \rightarrow 2)]-\alpha-L-$ arabinopyranosyl-17,20-didehydro-20-deoxyjujubogenin (6)

White amorphous powder; $[\alpha]_{\mathrm{D}}+8.9^{\circ}\left(c\right.$ 0.11, $\left.\mathrm{CH}_{3} \mathrm{OH}\right) ;{ }^{1} \mathrm{H}$ NMR $(\mathrm{MeOD}-\mathrm{d} 4,600 \mathrm{MHz})$ and ${ }^{13} \mathrm{C} \mathrm{NMR}$ (MeOD-d4, $150 \mathrm{MHz}$ ) of the aglycone part is identical to compound $4 \pm 0.2 \mathrm{ppm} ;{ }^{1} \mathrm{H}$ NMR (MeOD-d4, $600 \mathrm{MHz}$ ) and ${ }^{13} \mathrm{C}$ NMR (MeOD-d4, $150 \mathrm{MHz}$ ) of the osidic part, see Tables 4 and 5; HRESIMS (positive-ion mode) $m / z: 1079.5399[\mathrm{M}+\mathrm{Na}]^{+}\left(\right.$calcd for $\left.\mathrm{C}_{53} \mathrm{H}_{84} \mathrm{O}_{21} \mathrm{Na}, 1079.5403\right)$.

3.4.7. 3-O- $\beta$-D-xylopyranosyl- $(1 \rightarrow 6)$ - $\beta$-D-glucopyranosyl- $(1 \rightarrow 2)-\beta$-D-glucopyranosyl- $(1 \rightarrow 3)-[\alpha-L$ rhamnopyranosyl-(1 $\rightarrow 2)$ ]- $\alpha$-L-arabinopyranosyl-17,20-didehydro-20-deoxyjujubogenin (7)

White amorphous powder; $[\alpha]_{\mathrm{D}}+12.0^{\circ}\left(c \mathrm{0.1}, \mathrm{CH}_{3} \mathrm{OH}\right)$; ${ }^{1} \mathrm{H} \mathrm{NMR}(\mathrm{MeOD}-\mathrm{d} 4,600 \mathrm{MHz})$ and ${ }^{13} \mathrm{C} \mathrm{NMR}$ (MeOD-d4, $150 \mathrm{MHz}$ ) of the aglycone part is identical to compound $4 \pm 0.2 \mathrm{ppm} ;{ }^{1} \mathrm{H}$ NMR (MeOD-d4, 
$600 \mathrm{MHz}$ ) and ${ }^{13} \mathrm{C}$ NMR (MeOD-d4, $150 \mathrm{MHz}$ ) of the osidic part, see Tables 4 and 5; HRESIMS (positive-ion mode) $\mathrm{m} / \mathrm{z}: 1211.5817[\mathrm{M}+\mathrm{Na}]^{+}\left(\right.$calcd for $\left.\mathrm{C}_{58} \mathrm{H}_{92} \mathrm{O}_{25} \mathrm{Na}, 1211.5825\right)$.

3.4.8. 3-O- $\alpha$-L-arabinopyranosyl-( $(1 \rightarrow 6)$ - $\beta$-D-glucopyranosyl- $(1 \rightarrow 2)-\beta$-D-glucopyranosyl- $(1 \rightarrow 3)-[\alpha-L$ rhamnopyranosyl-(1 $\rightarrow 2)$ ]- $\alpha$-L-arabinopyranosyl-17,20-didehydro-20-deoxyjujubogenin $(\mathbf{8})$

White amorphous powder; $[\alpha]_{\mathrm{D}}-4.3^{\circ}\left(c 0.23, \mathrm{CH}_{3} \mathrm{OH}\right) ;{ }^{1} \mathrm{H} \mathrm{NMR}(\mathrm{MeOD}-\mathrm{d} 4,600 \mathrm{MHz})$ and ${ }^{13} \mathrm{C} \mathrm{NMR}$ (MeOD-d4, $150 \mathrm{MHz}$ ) of the aglycone part is identical to compound $4 \pm 0.2 \mathrm{ppm} ;{ }^{1} \mathrm{H}$ NMR (MeOD-d4, $600 \mathrm{MHz}$ ) and ${ }^{13} \mathrm{C}$ NMR (MeOD-d4, $150 \mathrm{MHz}$ ) of the osidic part, see Tables 4 and 5; HRESIMS (positive-ion mode) $\mathrm{m} / \mathrm{z}: 1211.5817[\mathrm{M}+\mathrm{Na}]^{+}\left(\right.$calcd for $\left.\mathrm{C}_{58} \mathrm{H}_{92} \mathrm{O}_{25} \mathrm{Na}, 1211.5825\right)$.

\subsubsection{7,20-didehydro-20-deoxyjujubogenin (9)}

White amorphous powder; $[\alpha]_{\mathrm{D}}+10.74^{\circ}\left(c \mathrm{c} .31, \mathrm{CH}_{3} \mathrm{OH}\right) ;{ }^{1} \mathrm{H}$ NMR $(\mathrm{MeOD}-\mathrm{d} 4,600 \mathrm{MHz})$ and ${ }^{13} \mathrm{C}$ NMR (MeOD-d4, $150 \mathrm{MHz}$ ), see Table 3; HRESIMS (positive-ion mode) $m / z: 477.3341[\mathrm{M}+\mathrm{Na}]^{+}$ (calcd for $\mathrm{C}_{30} \mathrm{H}_{46} \mathrm{O}_{3} \mathrm{Na}$. 477.3345).

\subsection{Sugar analysis and determination of absolute configuration}

$1 \mathrm{~g}$ of the crude hydromethanolic extract was refluxed with $25 \mathrm{~mL}$ of TFA ( $2 \mathrm{~N}$ ) for $4 \mathrm{~h}$. After extraction with EtOAc $(3 \times 25 \mathrm{~mL})$, the aqueous layer was neutralized to $\mathrm{pH} 6$ with $50 \mathrm{mM} \mathrm{KOH}$ and freeze-dried to provide the monosaccharide residue. The sugar profile was determined by comparison with authentic samples on TLC in MeCOEt-iso-PrOH-Me 2 CO- $\mathrm{H}_{2} \mathrm{O}$ (20:10:7:6). Each sugar was purified by semipreparative HPLC, on a specific column ROA $\left(250 \times 15 \mathrm{~mm}, \mathrm{~T}=35^{\circ} \mathrm{C}\right)$ eluted isocratically with a solution of $\mathrm{H}_{2} \mathrm{O} 0.25 \mu \mathrm{M} \mathrm{H}_{2} \mathrm{SO}_{4}$ at a flow rate of $3.5 \mathrm{~mL} / \mathrm{min}$ (Muhammad et al., 2015). After neutralization, each fraction was analyzed by HPLC on an analytical chiral column Chiralpak ${ }^{\circledR}$ ICA, using the mobile phase $n$-hexane-EtOH-TFA (80:20:0.1) isocratically at a flow rate of $0.5 \mathrm{~mL} / \mathrm{min}$ (Muhammad et al., 2015). Chromatograms were monitored by a refractive index detector RI-410 and identification of the sugars was carried out by comparing the retention times of standard D or L monosaccharide samples (Lopes and Gaspar, 2008). Four sugars were identified as L-rhamnose ( $\alpha \& \beta)$ at $R \mathrm{t} 11.7 \mathrm{~min}, \mathrm{~L}$-arabinose $(\alpha \& \beta)$ at $R \mathrm{t} 14.6-15.5 \mathrm{~min}, \mathrm{D}-\mathrm{xylose}(\alpha \& \beta)$ at $R \mathrm{t} 16.6-18.5$ and $\mathrm{D}-\mathrm{glucose}$ $(\alpha \& \beta)$ at $R \mathrm{t}$ 18.3-23.2 min.

\subsection{DPPH radical scavenging assay}

The radical scavenging activity of the EtOAc and hydromethanolic extracts of J. xerocarpa stems and bark was determined using the stable 1,1-diphenyl-2-picrylhydrazyl (DPPH) free radical (Muhammad et al., 2015, 2016) (See supplementary Information for details). 


\subsection{Tyrosinase inhibitory activity assay}

The tyrosinase inhibitory activity of the EtOAc and hydromethanolic extracts of J. xerocarpa stems and bark and the four lupane derivatives $(\mathbf{1 , 1 0 - 1 2})$ was determined against fungi tyrosinase. The assay was performed according to a previously described method using L-DOPA as substrate (Muhammad et al., 2015, 2016) (See supplementary Information for details).

\subsection{WST cytotoxicity assay}

The cytotoxic activities of compounds 1-3, 5-6, 10-12, 22, and 23 on KB cell lines (ATTC ${ }^{\circledR}$ CCL $^{\mathrm{TM}}-17$ ) were determined by using a colorimetry method based on the cleavage of the WST-1 tetrazolium salt, and using DMEM F12 medium for cells culture (Muhammad et al., 2015). $\alpha$-hederin was employed as a positive control, which exhibited an $\mathrm{IC}_{50}$ value of $5.5 \mu \mathrm{M}$ under the above conditions (Chwalek et al., 2006) (See supplementary Information for details).

\subsection{Disc diffusion antibacterial assay}

Disk diffusion was used to screened antibacterial activity of compounds 1-2, 5, 10-12, 22 and 23 against Staphylococcus aureus (ATCC 25923), Enterococcus faecalis (CIP10907) as gram positive bacteria, and Escherichia coli (ATCC 25922), Pseudomonas aeruginosa (ATCC 27853) as gram negative bacteria (Acebey-Castellon et al., 2011, Muhammad et al., 2016). The antimicrobial gentamicin was used as positive control and tested at $50 \mu \mathrm{g} / \mathrm{disk}$ (See supplementary Information for details).

\subsection{Broth diffusion antibacterial assay}

The liquid microdilution growth inhibition method (Acebey-Castellon et al., 2011, Yao-Kouassi et al., 2008) was used to determine the MIC values of the actives compounds $\mathbf{1}$ and $\mathbf{1 1}$ against both S. aureus and E. faecalis as previously described (Muhammad et al., 2016). The experiments were run in triplicate, and each time the MIC values were identical. Gentamicin $(25,12,5,5,2,5 \mu \mathrm{g} / \mathrm{mL})$ was used as inhibition growth positive control in the same conditions.

\section{Acknowledgments}

The authors thank the 'Région Champagne-Ardenne' and the 'Département de la Marne' for financial support. The EU-programme FEDER to the PIAneT CPER project is also gratefully acknowledged. Dominique HARAKAT (ICMR, UMR 7312) was also thanks to registry the MS spectra and Chantal Grimplet for the preparation of the microbial agar and liquid broths. 


\section{References}

Acebey-Castellon I., L., Voutquenne-Nazabadioko, L., Doan Thi Mai, H., Roseau, N., Bouthagane, N., Muhammad, D., Le Magrex Debar, E., Gangloff, S.C., Litaudon,M., Sevenet, T., Van Hung, N., Lavaud, C., 2011. Triterpenoid saponins from Symplocos lancifolia. J. Nat. Prod. 74, 163-168 Agrawal, P.K., 1992. NMR spectroscopy in the structural elucidation of oligosaccharides and glycosides. Phytochemistry 31, 3307-3330.

Baillon, H., 1876, Adansonia; recueil d'observations botaniques. Paris.. Vol. 11. 270.

Chang, J., Case, R., 2005. Phenolic glycosides and ionone glycoside from the stem of Sargentodoxa cuneata. Phytochemistry 66, 2752-2758.

Chwalek, M, Lalun, N, Bobichon, H, Ple, K, Voutquenne-Nazabadioko, L., 2006. Structure-activity relationships of some hederagenin diglycosides: haemolysis, cytotoxicity and apoptosis induction. Biochem. Biophys. Acta 1760, 1418-1427

Dzubak, P., Hajduch, M., Vydra, D., Hustova, A., Kvasnica, M., Biedermann, D., Markova, L., Urban, M., Sarek, J., 2006. Pharmacological activities of natural triterpenoids and their therapeutic implications. Nat. Prod. Rep. 23, 394-411.

Guo, S., Tang, Y.P., Duan, J.A., Su, S.L., Ding, A.W., 2009. Two new terpenoids from fruits of Ziziphus jujuba. Chin. Chem. Lett. 20, 197-200.

Guillaumin, A., Flore de la Nouvelle calédonie. 1948: p. 202-203.

Hopkins, H. C. F., Pillon, Y., Stacy, E. A., Kellermann, J., 2015. Jaffrea, a new genus of Rhamnaceae endemic to New Caledonia, with notes on Alphitonia and Emmenosperma, Kew Bulletin 70:42, DOI 10.1007/S12225-015-9593-6

Ji, C.-J., Zeng, G.-Z., Han, J., He, W.-J., Zhang, Y.-M., Tan, N.-H., 2012. Zizimauritic acids A-C, three novel nortriterpenes from Ziziphus mauritiana. Bioorg Med Chem Lett, 22, 6377-80.

Jou, S.J., Chen, C.H., Guh, J.H., Lee, C.N., Lee, S.S., 2004. Flavonol glycosides and cytotoxic triterpenoids from Alphitonia philippinensis. J. Chin. Chem. Soc. 51, 827-834.

Krenn, L., Presser, A., Pradhan, R., Bahr, B., Papper, D.H., Mayer, K.K., Kopp, B., 2003. Sulfemodin 8O- $\beta$-D-glucoside, a new sulfated anthraquinone glycoside, and antioxidant phenolic compounds from Rheum emodi. J. Nat. Prod. 66, 1107-1109.

Kuo, Y.H.Shue, M.J., 1991. New esters, 2-(4-hydroxy-3-methoxyphenyl)ethyl hexa- and octacosanoates from the leaves of Cinnamomum reticulatum Hay. J. Chin. Chem. Soc. 38, 65-9.

Kundu, A.B., Barik, B.R., Mondal, D.N., Dey, A.K., Banerji, A., 1989. Zizyberanalic acid, a pentacyclic triterpenoid of Zizyphus jujuba. Phytochemistry 28, 3155-8. 
Lallemand, J.Y., Duteil, M., 1977. Carbon-13 NMR spectra of quercetin and rutin Org. Magn. Res. 9, $179-80$

Lee, S.M., Min, B.S., Lee, C.-G., Kim, K.-S., Kho, Y.H., 2003. Cytotoxic triterpenoids from the fruits of Zizyphus jujuba. Planta Med. 69,1051-1054.

Li, Y.-L., Li, J., Wang, N.-L., Yao, X.-S., 2008. Flavonoids and a New Polyacetylene from Bidens parviflora Willd. Molecules 13, 1931-1941

Lin, R.C., Bourdy, G., Lacaille-Dubois, M.A., 1995. Flavonoids from Alphitonia neocaledonica. Planta Med. 61, 197.

Lopes, J.F., Gaspar, E.M.S.M., 2008. Simultaneaous chromatographic separation of enantiomers, anomers and structural isomers of some biologically relevant monosaccharides. J. Chrom. A 1188, 34-42

Lue, B.-M., Nielsen, N.S., Jacobsen, C., Hellgren, L., Guo, Z., Xu, X., 2010. Antioxidant properties of modified rutin esters by DPPH, reducing power, iron chelation and human low density lipoprotein assays. Food Chem. 123, 221-230.

Morat, P., Jaffré, T., Tronchet, F., Munzinger, J., Pillon, Y., Veillon, J.-M., Chalopin, M. 2012. Le référentiel taxonomique Florical et les caractéristiques de la flore vasculaire indigène de la NouvelleCalédonie. Adansonia, sér. 3, 34, 179-221. http://dx.doi.org/10.5252/a2012n2a1

Muhammad, D., Hubert, J., Lalun, N., Renault, J.H., Bobichon, H., Nour, M., VoutquenneNazabadioko, L. 2015. Isolation of flavonoids and triterpenoids from the fruits of Alphitonia neocaledonica and evaluation of their anti-oxidant, anti-tyrosinase and cytotoxic activities. Phytochem Anal. 26, 137-144.

Muhammad, D., Lalun, N., Bobichon, E. Le Magrex Debar, S. C. Gangloff, Nour, M., VoutquenneNazabadioko, L. 2016. Flavonoids and triterpenoids from the leaves of Alphitonia xerocaprus Baill and their biological activities. Phytochemistry 129, 45-57.

Munzinger, J., Morat, Ph., Jaffré, T., Gâteblé, G., Pillon, Y., Tronchet, F., Veillon, J.-M., M. Chalopin. 2016. FLORICAL: Checklist of the vascular indigenous flora of New Caledonia. vers. 22.IV.2016. Nuengchamnong, N., Sookying, S., Ingkaninan, K., 2016. LC-ESI-QTOF-MS based screening and identification of isomeric jujubogenin and pseudojujubogenin aglycones in Bacopa monnieri extract. J. Pharm. Biomed. Anal. 129, 121-134.*

Okamura, N., Nohara, T., Yagi, A., Nishioka, I., 1981. Studies on the Constituents of Zizyphi Fructus. III. Structures of Dammarane-type Saponins. Chem. Pharm. Bull. 29, 676-683.

Pawar, R.S., Khan, S.I., Khan, I.A., 2007. Glycosides of 20-deoxy derivatives of jujubogenin and pseudojujubogenin from Bacopa monniera. Planta Med. 73, 380-383.* 
Pretsch, E., Clerc, T., Seibl, J., Simon, W., Tables of spectral data for structure determination of organic compounds1989, Berlin Heidelberg Springer-Verlag

Sugiyama, M.Kikuchi, M., 1992. Studies on the constituents of Osmanthus species. X. Structures of phenolic glucosides from the leaves of Osmanthus asiaticus Nakai. Chem. Pharm. Bull., 40, 325-326.

Wang, Y., Ding, B., Luo, D., Chen, L.-Y., Hou, Y.-L., Dai, Y., Yao, X.-S., 2013. New triterpene glycosides from Ziziphi Spinosae Semen. Fitoterapia 90, 185-191.

Yao-Kouassi, P.A., Alabdul Magid, A., Richard, B., Martinez, A., Jacquier, M.J., Caron, C., Le Magrex Debar, E., Gangloff, S. C., Coffy, A. A., Zèches-Hanrot, M., 2008. Isoflavonoid glycosides from the roots of Baphia bancoensis. J. Nat. Prod. 71, 2073-2076.

Yoshikawa, K., Eiko, K., Mimura, N., Kondo, Y., Arihara, S., 1998. Hovetrichosides C-G, five new glycosides of two auronols, two neolignans, and a phenylpropanoid from the bark of Hovenia trichocarea. J. Nat. Prod. 61, 786-790.

*The name 20-deoxyjujubogenin used in these references is wrong. The correct name is 17,20-didehydro20-deoxyjujubogenin.

\section{Supporting information}

1D and 2D NMR spectra of compounds 1-9 can be found in the online version of this article.

\section{Figure caption}

Fig. 1: Structures of isolated compounds 1-17, 19-21 and 23 

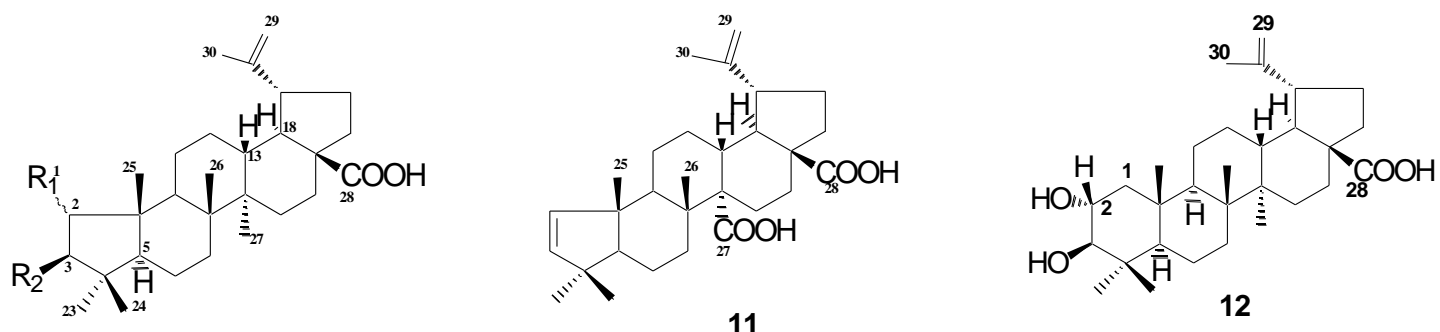

1: $\mathrm{R}_{1}=\alpha-\mathrm{CHO}, \mathrm{R}_{2}=\mathrm{H}$

2: $R_{1}=\beta-C H O, R_{2}=H$

10: $\mathrm{R}_{1}=\alpha-\mathrm{COOH}, \mathrm{R}_{2}=\mathrm{OH}$

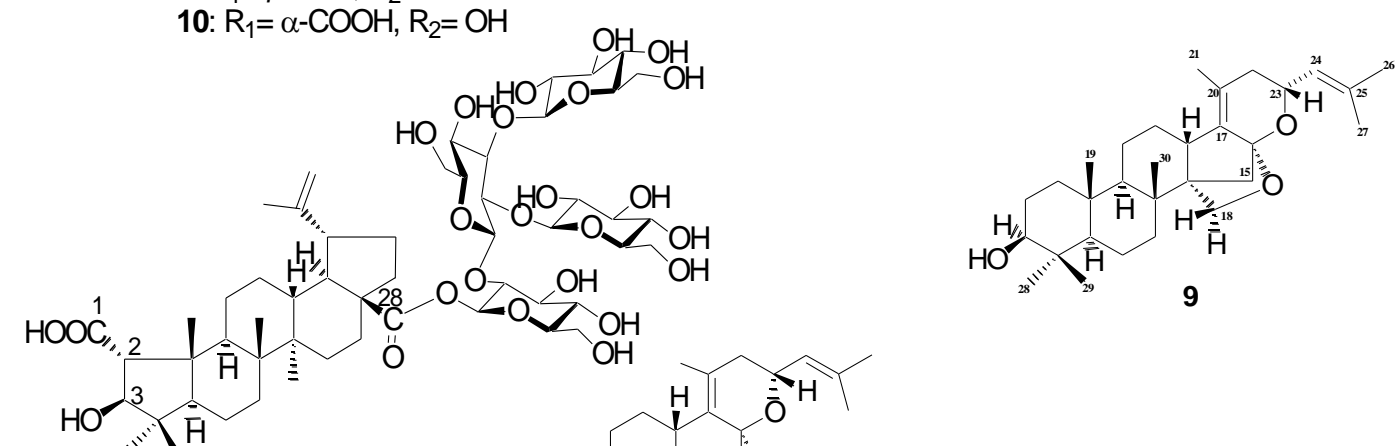

$\mathrm{HO}^{3}$ तิ

(3)

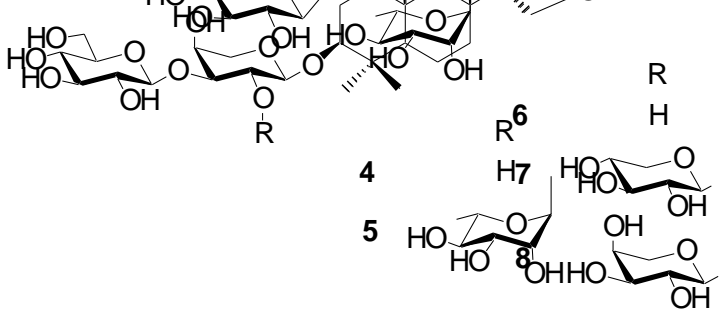

"O

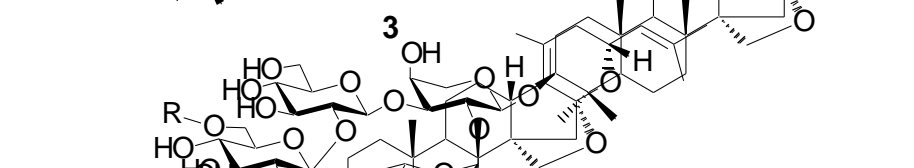

$$
\text { 光 }
$$$$
\text { (1) }
$$

(-O)

(5)

$$
\begin{aligned}
& \mathrm{HO} \widehat{\mathrm{HO}} \mathrm{OH} \\
& 13 \mathrm{H} \\
& 14 \mathrm{SO}_{3} \mathrm{Na}
\end{aligned}
$$$$
16{ }_{\mathrm{OH}}^{\mathrm{HQOH}}
$$

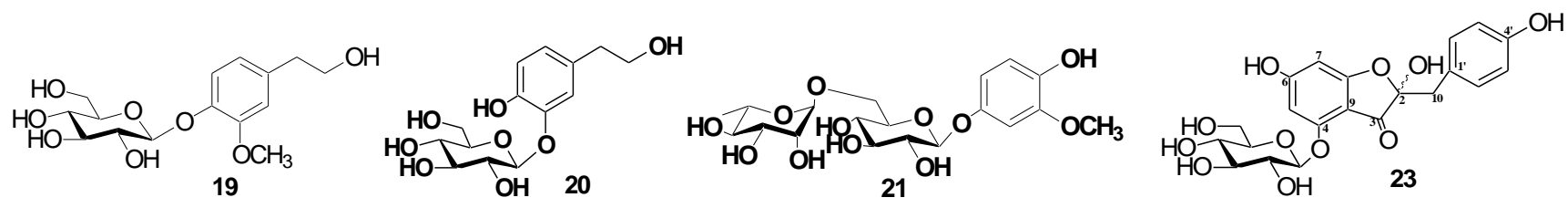

Fig. 1: Structures of isolated compounds 1-17, 19-21 and 23 
Table 1: ${ }^{1} \mathrm{H}$ and ${ }^{13} \mathrm{C}-\mathrm{NMR}$ data of compounds $\mathbf{1}$ and $\mathbf{2}$

\begin{tabular}{|c|c|c|c|c|}
\hline \multirow[b]{2}{*}{ Position } & \multicolumn{2}{|l|}{$\mathbf{1}^{\mathbf{a}}$} & \multicolumn{2}{|l|}{$2^{b}$} \\
\hline & $\delta_{\mathrm{C}}$ & $\delta_{\mathrm{H}}(m, J$ in $\mathrm{Hz})$ & $\delta_{\mathrm{C}}$ & $\delta_{\mathrm{H}}(m, J$ in $\mathrm{Hz})$ \\
\hline 1 & 205.3 & $9.84(d, 3.5)$ & 206.6 & $9.73(d, 4.7)$ \\
\hline 2 & 61.5 & $2.58(d d, 7.8,3.5)$ & 64.1 & $2.25(d d d, 9.8,4.7,3.6)$ \\
\hline 3 & 39.1 & $\begin{array}{l}1.81(d d, 14.5,7.8) \\
1.91(d d, 14.5,0.9)\end{array}$ & 40.4 & $\begin{array}{l}1.61(d d, 13.6,3.6) \\
1.99(d d, 13.6,9.8)\end{array}$ \\
\hline 4 & 38.3 & - & 37.7 & - \\
\hline 5 & 58.7 & $1.25(d d, 9.1,2.8)$ & 63.1 & $1.07(d d, 8.9,2.6)$ \\
\hline 6 & 18.5 & $\begin{array}{l}1.37(\mathrm{~m}) \\
1.42(\mathrm{~m})\end{array}$ & 17.9 & $\begin{array}{l}1.40(\mathrm{~m}) \\
1.40(\mathrm{~m})\end{array}$ \\
\hline 7 & 34.0 & $\begin{array}{l}1.37(\mathrm{~m}) \\
1.37(\mathrm{~m})\end{array}$ & 34.3 & $\begin{array}{l}1.40(\mathrm{~m}) \\
1.40(\mathrm{~m})\end{array}$ \\
\hline 8 & 41.6 & - & 41.7 & - \\
\hline 9 & 44.9 & $1.73(d d, 12.8,2.9)$ & 50.1 & $1.65(d d, 16.3,3.7)$ \\
\hline $\mathbf{1 0}$ & 52.0 & - & 51.1 & - \\
\hline 11 & 23.7 & $\begin{array}{l}1.51(d d, 9.6,1.8) \\
1.65(d d, 13.5,3.9)\end{array}$ & 24.3 & $\begin{array}{l}1.23(\mathrm{~m}) \\
1.50(d d, 13.3,4.7)\end{array}$ \\
\hline 12 & 24.9 & $\begin{array}{l}1.09(d d, 12.9,4.9) \\
1.72(m)\end{array}$ & 25.1 & $\begin{array}{l}1.15(d d, 11.7,5.1) \\
1.71(d m, 5.8)\end{array}$ \\
\hline 13 & 38.6 & $2.22(t d, 12.2,3.6)$ & 38.3 & $2.19(t d, 12.2,3.8)$ \\
\hline 14 & 42.8 & - & 42.6 & - \\
\hline 15 & 29.9 & $\begin{array}{l}1.20(d t, 13.7,3.2) \\
1.58(t d, 12.9,4.2)\end{array}$ & 29.9 & $\begin{array}{l}1.21(\mathrm{dt}, 13.8,3.5) \\
1.59(\mathrm{tm}, 13.5)\end{array}$ \\
\hline 16 & 32.2 & $\begin{array}{l}1.44(d d, 9.8,3.4) \\
2.30(d t, 12.9,3.3)\end{array}$ & 32.2 & $\begin{array}{l}1.47(d d, 13.5,3.3) \\
2.30(t d, 13.0,3.3)\end{array}$ \\
\hline 17 & 56.3 & - & 56.2 & - \\
\hline 18 & 49.2 & $1.62(t, 11.5)$ & 49.3 & $1.62(t, 11.5)$ \\
\hline 19 & 46.9 & $3.01(t d, 10.9,4.9)$ & 47.0 & $3.01(t d, 10.8,5.1)$ \\
\hline 20 & 150.2 & - & 150.1 & - \\
\hline 21 & 30.5 & $\begin{array}{l}1.43(d d, 10.1,3.2) \\
2.01(\mathrm{~m})\end{array}$ & 30.5 & $\begin{array}{l}1.44(d d, 13.1,3.1) \\
2.01(m)\end{array}$ \\
\hline 22 & 37.1 & $\begin{array}{l}1.50(m) \\
1.99(d m, 9.1)\end{array}$ & 37.1 & $\begin{array}{l}1.50(\mathrm{~m}) \\
2.00(d d, 11.3,4.3)\end{array}$ \\
\hline 23 & 32.0 & $1.12(s)$ & 32.5 & $1.03(s)$ \\
\hline 24 & 26.2 & $0.97(s)$ & 25.8 & $0.98(s)$ \\
\hline 25 & 19.3 & $0.99(s)$ & 13.5 & $1.03(s)$ \\
\hline 26 & 16.9 & $0.96(s)$ & 16.6 & $0.94(s)$ \\
\hline 27 & 14.8 & $0.96(s)$ & 14.7 & $1.02(s)$ \\
\hline 28 & 181.9 & - & 181.0 & - \\
\hline 29 & 109.9 & $\begin{array}{l}4.64(d d, 2.2,1.5) \\
4.75(d, 2.2)\end{array}$ & 110.0 & $\begin{array}{l}4.63(d d, 2.2,1.4) \\
4.75(d, 2.3)\end{array}$ \\
\hline 30 & 19.3 & $1.70(s)$ & 19.3 & $1.70(s)$ \\
\hline
\end{tabular}

${ }^{\text {a }} \mathrm{NMR}$ data were measured in $\mathrm{CDCl}_{3}$ at $600 \mathrm{MHz}\left({ }^{1} \mathrm{H}\right)$ and $150 \mathrm{MHz}\left({ }^{13} \mathrm{C}\right)$

${ }^{\mathrm{b}} \mathrm{NMR}$ data were measured in $\mathrm{CDCl}_{3}+\mathrm{CD}_{3} \mathrm{OD}$ at $500 \mathrm{MHz}\left({ }^{1} \mathrm{H}\right)$ and $125 \mathrm{MHz}\left({ }^{13} \mathrm{C}\right)$ 
Table 2: ${ }^{1} \mathrm{H}(500 \mathrm{MHz})$ and ${ }^{13} \mathrm{C}(125 \mathrm{MHz}) \mathrm{NMR}$ data of 3 in $\mathrm{CD}_{3} \mathrm{OD}$.

\begin{tabular}{|c|c|c|c|c|c|}
\hline Position & $\delta_{\mathbf{C}}$ & $\delta_{\mathrm{H}}(m, J$ in $\mathrm{Hz})$ & Position & $\delta_{\mathrm{C}}$ & $\delta_{\mathrm{H}}(m, J$ in $\mathrm{Hz})$ \\
\hline 1 & 177.4 & - & $\mathrm{C}_{28}$-Glc & & \\
\hline 2 & 65.6 & $2.50(b r s)$ & $\mathbf{1}^{\prime}$ & 92.0 & $5.62(d, 7.9)$ \\
\hline 3 & 84.5 & $4.10(b r s)$ & $2^{\prime}$ & 76.4 & $3.87(d d, 9.6,7.9)$ \\
\hline 4 & 42.9 & - & $3^{\prime}$ & 77.0 & $3.80(d d, 9.6,8.5)$ \\
\hline 5 & 56.7 & $1.70(\mathrm{~m})$ & $4^{\prime}$ & 69.3 & $3.43(t, 9.6)$ \\
\hline \multirow[t]{2}{*}{6} & 18.3 & $1.35(\mathrm{~m})$ & $5^{\prime}$ & 77.4 & $3.43(m)$ \\
\hline & & $1.54(\mathrm{~m})$ & $6^{\prime}$ & 60.9 & $3.72(d d, 12.3,4.7)$ \\
\hline \multirow[t]{2}{*}{7} & 34.1 & $1.37(\mathrm{~m})$ & & & $3.86(d d, 12.3,1.7)$ \\
\hline & & $1.45(\mathrm{~m})$ & $\mathrm{C}_{2}$-Glc & & \\
\hline 8 & 41.7 & - & 1" & 101.2 & $5.04(d, 7.4)$ \\
\hline 9 & 44.4 & $1.78(d d, 12.5,2.5)$ & $2^{\prime \prime}$ & 81.2 & $3.65(t, 8.0)$ \\
\hline 10 & 49.0 & - & $3^{\prime \prime}$ & 86.2 & $3.69(t, 8.4)$ \\
\hline \multirow[t]{2}{*}{11} & 23.2 & $1.50(\mathrm{~m})$ & $4^{\prime \prime}$ & 69.7 & $3.30(\mathrm{~m})$ \\
\hline & & $1.59(\mathrm{~m})$ & $5 "$ & 75.4 & $3.32(m)$ \\
\hline \multirow[t]{2}{*}{12} & 25.3 & $1.09(\mathrm{~m})$ & $6 "$ & 69.9 & $3.60(d d, 11.6,6.5)$ \\
\hline & & $1.68(\mathrm{~m})$ & & & $3.93(d d, 11.6,2.2)$ \\
\hline 13 & 38.3 & $2.25(t d, 11.8,3.6)$ & $\mathrm{C}_{2 "-G l c}$ & & \\
\hline 14 & 42.8 & - & $1^{\prime \prime \prime}$ & 103.4 & $4.73(d, 7.8)$ \\
\hline \multirow[t]{2}{*}{15} & 30.9 & $1.13(\mathrm{~m})$ & $2^{\prime \prime \prime}$ & 74.5 & $3.24(t, 8.4)$ \\
\hline & & $1.59(\mathrm{~m})$ & $3^{\prime \prime \prime}$ & 76.1 & $3.40(t, 9.0)$ \\
\hline \multirow[t]{2}{*}{16} & 31.3 & $1.45(\mathrm{~m})$ & $4^{\prime \prime \prime}$ & 70.0 & $3.37(\mathrm{~m})$ \\
\hline & & $2.57(\mathrm{dm}, 12.7)$ & $5 " '$ & 76.9 & $3.36(m)$ \\
\hline 17 & 56.7 & - & $6^{\prime \prime \prime}$ & 61.1 & $3.77(d d, 12.0,4.1)$ \\
\hline 18 & 49.4 & $1.65(t, 11.0)$ & & & $3.99(d d, 12.1,1.7)$ \\
\hline 19 & 46.9 & $3.02(t d, 11.0,4.8)$ & C3"-Glc & & \\
\hline 20 & 150.4 & - & $1^{\prime \prime \prime \prime}$ & 103.4 & $4.59(d, 7.8)$ \\
\hline \multirow[t]{2}{*}{21} & 30.2 & $1.38(\mathrm{~m})$ & $2^{\prime \prime \prime \prime}$ & 74.0 & $3.30(t, 8.4)$ \\
\hline & & $1.90(t, 10.7)$ & $3^{\prime \prime \prime \prime}$ & 76.8 & $3.42,(m)$ \\
\hline \multirow[t]{2}{*}{22} & 36.2 & $1.50(t, 12.5)$ & $4^{\prime \prime \prime \prime}$ & 70.2 & $3.30(t, 8.9)$ \\
\hline & & $2.04(d d, 12.4,8.2)$ & $5 " ' "$ & 76.8 & $3.38,(m)$ \\
\hline 23 & 30.0 & $1.10(s)$ & $6^{\prime \prime \prime \prime}$ & 61.2 & $3.65(d d, 11.9,6.7)$ \\
\hline 24 & 18.5 & $0.94(s)$ & & & $3.92(d d, 11.9,2.3)$ \\
\hline 25 & 17.9 & $1.09(s)$ & & & \\
\hline 26 & 16.4 & $1.02(s)$ & & & \\
\hline 27 & 14.0 & $1.01(s)$ & & & \\
\hline 28 & 174.5 & - & & & \\
\hline 29 & 18.2 & $1.71(s)$ & & & \\
\hline \multirow[t]{2}{*}{30} & 108.8 & $4.61(b r s)$ & & & \\
\hline & & 4.73 (brs) & & & \\
\hline
\end{tabular}


Table 3: ${ }^{1} \mathrm{H}$ and ${ }^{13} \mathrm{C}$ NMR data of the aglycone of compounds 4 and 9 in $\mathrm{CD}_{3} \mathrm{OD}$.

\begin{tabular}{|c|c|c|c|c|}
\hline \multirow[b]{2}{*}{ Position } & \multicolumn{2}{|l|}{$4^{\mathrm{a}}$} & \multicolumn{2}{|l|}{$9^{b}$} \\
\hline & $\delta_{\mathrm{C}}$ & $\delta_{\mathrm{H}}(m, J$ in $\mathrm{Hz})$ & $\delta_{\mathrm{C}}$ & $\delta_{\mathrm{H}}(m, J$ in $\mathrm{Hz})$ \\
\hline \multirow[t]{2}{*}{1} & 38.6 & $0.98(t d, 14.2,5.0)$ & 38.3 & $0.99(t d, 13.2,3.9)$ \\
\hline & & $1.71(\mathrm{~m})$ & & $1.74(d d d, 12.3,4.3,2.2)$ \\
\hline \multirow[t]{2}{*}{2} & 26.0 & $1.73(d l, 16.9,5.9)$ & 26.6 & $1.60(d d d, 11.6,6.3,3.7)$ \\
\hline & & $1.87(d d, 18.5,4.6)$ & & $1.64(d d, 13.3,3.8)$ \\
\hline 3 & 88.2 & $3.14(d d, 11.9,4.7)$ & 78.0 & $3.15(d d, 11.4,5.0)$ \\
\hline 4 & 39.1 & - & 38.7 & - \\
\hline 5 & 56.1 & $0.78(d m, 11.2)$ & 55.6 & $0.76(d d, 11.3,2.4)$ \\
\hline \multirow[t]{2}{*}{6} & 17.7 & $1.53(d m, 9.5)$ & 17.8 & $1.55(d d, 9.6,3.6)$ \\
\hline & & $1.63(d d, 13.5,8.2)$ & & $1.63(m)$ \\
\hline \multirow[t]{2}{*}{7} & 34.9 & $1.52(d d, 10.6,2.5)$ & 34.9 & $1.52(d d, 13.3,2.6)$ \\
\hline & & $1.63(d d, 13.5,8.2)$ & & $1.62(d d, 12.0,1.3)$ \\
\hline 8 & 36.7 & - & 36.7 & - \\
\hline 9 & 52.5 & $0.91(d d, 12.9,5.8)$ & 52.4 & $0.92(d d, 13.1,3.3)$ \\
\hline 10 & 36.8 & - & 37.1 & - \\
\hline \multirow[t]{2}{*}{11} & 20.7 & $1.54(d d, 11.4,2.5)$ & 20.7 & $1.54(d d, 16.7,3.8)$ \\
\hline & & $1.70(d d, 9.4,1.5)$ & & $1.70(\mathrm{~m})$ \\
\hline \multirow[t]{2}{*}{12} & 25.3 & $1.75(d d, 8.0,6.3)$ & 25.3 & $1.74(d d, 13.2,2.1)$ \\
\hline & & $2.21(d d d, 16.1,9.6,4.6)$ & & $2.23(d d d, 13.5,5.0,2.3)$ \\
\hline 13 & 41.3 & $2.87(d, 10.6)$ & 41.4 & $2.87(d m, 11.7)$ \\
\hline 14 & 53.4 & - & 53.5 & - \\
\hline \multirow[t]{2}{*}{15} & 39.9 & $1.38(d, 9.2)$ & 39.9 & $1.38(d, 9.2)$ \\
\hline & & $1.80(d, 9.2)$ & & $1.80(d, 9.3)$ \\
\hline 16 & 106.8 & - & 106.8 & - \\
\hline 17 & 133.5 & - & 133.6 & - \\
\hline 18 & 66.1 & 4.08 (brs) & 66.1 & 4.08 (brs) \\
\hline 19 & 15.4 & $0.90(s)$ & 15.2 & $0.90(s)$ \\
\hline 20 & 124.1 & - & 124.1 & - \\
\hline 21 & 16.2 & $1.67(s)$ & 16.2 & $1.67(s)$ \\
\hline \multirow[t]{2}{*}{22} & 35.6 & $4.70(d d, 20.4,10.1)$ & 35.6 & $1.81(d t, 18.6,3.4)$ \\
\hline & & $1.93(d d d, 20.1,4.6,2.8)$ & & $1.92(d d d, 11.2,3.6,1.2)$ \\
\hline \multirow[t]{2}{*}{23} & 69.0 & $4.70(d d d, 15.8,8.1,3.5)$ & 69.0 & $4.71(d d d, 11.5,7.9,3.4)$ \\
\hline & & & & - \\
\hline 24 & 124.4 & $5.20(d t, 8.5,1.4)$ & 124.4 & $5.19(d t, 8.4,1.4)$ \\
\hline 25 & 136.5 & - & 135.5 & - \\
\hline 26 & 24.4 & $1.76(\mathrm{~s})$ & 24.4 & $1.76(s)$ \\
\hline 27 & 17.0 & $1.72(\mathrm{~s})$ & 17.0 & $1.72(s)$ \\
\hline 28 & 27.0 & $1.05(\mathrm{~s})$ & 27.2 & $0.99(s)$ \\
\hline 29 & 15.7 & $0.89(\mathrm{~s})$ & 14.7 & $0.80(s)$ \\
\hline 30 & 17.8 & $1.12(s)$ & 17.8 & $1.13(s)$ \\
\hline
\end{tabular}

${ }^{\text {a }} \mathrm{NMR}$ data were measured in $\mathrm{CD}_{3} \mathrm{OD}$ at $600 \mathrm{MHz}\left({ }^{1} \mathrm{H}\right)$ and $150 \mathrm{MHz}\left({ }^{13} \mathrm{C}\right)$

${ }^{\mathrm{b}} \mathrm{NMR}$ data were measured in $\mathrm{CD}_{3} \mathrm{OD}$ at $500 \mathrm{MHz}\left({ }^{1} \mathrm{H}\right)$ and $125 \mathrm{MHz}\left({ }^{13} \mathrm{C}\right)$ 
Table 4: ${ }^{1} \mathrm{H}$ NMR data of the osidic part of compounds 4-8 in $\mathrm{CD}_{3} \mathrm{OD}$.

\begin{tabular}{|c|c|c|c|c|c|}
\hline & $4^{a}$ & $5^{b}$ & $6^{b}$ & $7^{a}$ & $8^{a}$ \\
\hline $\begin{array}{c}\text { Position } \\
\text { C-3-Ara }\end{array}$ & $\delta_{\mathrm{H}}(m, J$ in $\mathrm{Hz})$ & $\delta_{\mathrm{H}}(m, J$ in $\mathrm{Hz})$ & $\delta_{\mathrm{H}}(m, J$ in $\mathrm{Hz})$ & $\delta_{\mathrm{H}}(m, J$ in $\mathrm{Hz})$ & $\delta_{\mathrm{H}}(m, J$ in $\mathrm{Hz})$ \\
\hline $\mathbf{1}^{\prime}$ & $4.30(d, 7.4)$ & $4.52(d, 7.7)$ & $4.39(d, 6.5)$ & $4.40(d, 6.5)$ & $4.40(d, 6.5)$ \\
\hline $\mathbf{2}^{\prime}$ & $3.73(d d, 9.4,7.4)$ & $3.90(d d, 8.5,7.5)$ & $3.90(d d, 8.9,6.5)$ & $3.90(d d, 9.2,6.5)$ & $3.91(d d, 8.7,6.5)$ \\
\hline $3^{\prime}$ & $3.66(d d, 9.4,3.3)$ & $3.88(d d, 8.5,3.3)$ & $3.88(t, 9.1)$ & $3.87(t, 9.2)$ & $3.87(d d, 9.0,2.7)$ \\
\hline $4^{\prime}$ & $4.05(m)$ & $4.04(m)$ & $4.07(m)$ & $4.07(m)$ & $4.07(m)$ \\
\hline \multirow[t]{2}{*}{$5^{\prime}$} & $3.57(d d, 12.6,1.3)$ & $3.52(d d, 11.9,1.4)$ & $3.57(d d, 12.5,1.6)$ & $3.55(d d, 12.5,1.4)$ & $3.55(d d, 12.5,1.8)$ \\
\hline & $3.87(d d, 12.5,2.5)$ & $3.89(d d, 11.9,2.5)$ & $3.86(d d, 12.5,2.6)$ & $3.87(d d, 12.5,3.0)$ & $3.87(d d, 12.5,3.0)$ \\
\hline \multicolumn{6}{|c|}{ C-2'-Rha } \\
\hline $1^{\prime \prime}$ & & $5.24(d, 1.5)$ & $5.20(d, 1.6)$ & $5.27(d, 1.4)$ & $5.31(d, 1.3)$ \\
\hline $2^{\prime \prime}$ & & $3.93(d d, 3.3,1.7)$ & $3.94(d d, 3.3,1.7)$ & $4.06(m)$ & $4.03(d d, 3.2,1.7)$ \\
\hline 3" & & $3.73(d d, 9.7,3.6)$ & $3.72(d d, 9.7,3.7)$ & $3.73(d d, 9.5,3.4)$ & $3.74(d d, 9.6,3.4)$ \\
\hline $4^{\prime \prime}$ & & $3.41(t, 9.6)$ & $3.44(t, 9.8)$ & $3.43(t, 9.5)$ & $3.44(t, 9.6)$ \\
\hline $5 "$ & & $3.88(m)$ & $3.37(d q, 9.8,6.3)$ & $3.97(m)$ & $3.97(d q, 9.6,6.3)$ \\
\hline 6" & & $1.24(d, 6.2)$ & $1.24(d, 6.3)$ & $1.25(d, 6.2)$ & $1.25(d, 6.2)$ \\
\hline \multicolumn{6}{|l|}{ C-3'-Glc } \\
\hline $1 " \prime$ & $4.57(d, 7.7)$ & $4.51(d, 7.7)$ & $4.66(d, 7.3)$ & $4.70(d, 7.5)$ & $4.70(d, 7.5)$ \\
\hline $2^{\prime \prime \prime}$ & $3.31(\mathrm{~m})$ & $3.31(d d, 8.9,7.6)$ & $3.62(d d, 9.1,7.2)$ & $3.71(t, 8.1)$ & $3.71(d d, 9.0,7.5)$ \\
\hline $3^{\prime \prime \prime}$ & $3.40(t, 8.9)$ & $3.40(t, 8.8)$ & $3.61(t, 9.1)$ & $3.63(d d, 9.0,8.1)$ & $3.64(t, 9.0)$ \\
\hline $4^{\prime \prime \prime}$ & $3.36(t, 8.9)$ & $3.36(t, 8.7)$ & $3.39(t, 9.0)$ & $3.40(t, 9.0)$ & $3.40(t, 9.6)$ \\
\hline $5 " \prime$ & $3.31(m)$ & $3.33(d, 8.2)$ & $3.32(m)$ & $3.34(m)$ & $3.34(m)$ \\
\hline \multirow[t]{2}{*}{ 6"' } & $3.86(d d, 11.6,5.2)$ & $3.70(d d, 12.0,2.1)$ & $3.68(d d, 11.9,5.5)$ & $3.69(d d, 11.9,5.6)$ & $3.69(d d, 12.0,5.2)$ \\
\hline & $3.70(d d, 11.4,2.8)$ & $3.86(d d, 12.0,2.1)$ & $3.88(d d, 11.9,2.3)$ & $3.86(d d, 8.8,3.0)$ & $3.86(d d, 12.0,2.5)$ \\
\hline \multicolumn{6}{|l|}{ C-2"'-Glc } \\
\hline $1^{\prime \prime \prime \prime}$ & & & $4.77(d, 7.4)$ & $4.89(d, 7.3)$ & $4.88(d, 7.3)$ \\
\hline $2^{\prime \prime \prime \prime}$ & & & $3.39(m)$ & $3.43(t, 8.9)$ & $3.43(t, 8.8)$ \\
\hline $3^{\prime \prime \prime \prime}$ & & & $3.39(\mathrm{~m})$ & $3.38(t, 9.0)$ & $3.40(t, 9.0)$ \\
\hline $4^{\prime \prime \prime \prime}$ & & & $3.39(t, 8.6)$ & $3.45(t, 8.9)$ & $3.42(t, 9.2)$ \\
\hline $5^{\prime \prime \prime \prime}$ & & & $3.31(m)$ & $3.39(m)$ & $3.47(m)$ \\
\hline \multirow[t]{2}{*}{ 6"'" } & & & $3.68(d d, 11.9,5.5)$ & $3.79(d d, 11.4,4.6)$ & $3.80(d d, 11.4,5.6)$ \\
\hline & & & $3.91(d d, 12.0,2.6)$ & $4.16(d d, 11.4,1.5)$ & $4.16(d d, 11.4,2.4)$ \\
\hline C-6"'" & & & & Xyl & Ara \\
\hline 1"'"' & & & & $4.34(d, 7.5)$ & $4.36(d, 6.8)$ \\
\hline 2"'"' & & & & $3.31(t, 8.6)$ & $3.65(d d, 9.1,6.9)$ \\
\hline $3^{\prime \prime \prime \prime \prime}$ & & & & $3.38(t, 9.0)$ & $3.61(d d, 9.1,3.4)$ \\
\hline $4^{\prime \prime \prime \prime \prime}$ & & & & $3.52(d d d, 10.6,9.0,5.4)$ & $3.83(t d, 3.4,2.5)$ \\
\hline \multirow[t]{2}{*}{$5 " \cdots " '$} & & & & $3.25(d d, 11.4,10.5)$ & $3.61(d d, 11.4,3.4)$ \\
\hline & & & & $3.90(d d, 11.4,5.4)$ & $3.90(d d, 11.3,2.5)$ \\
\hline
\end{tabular}

${ }^{\text {a }} \mathrm{NMR}$ data were measured in $\mathrm{CD}_{3} \mathrm{OD}$ at $600 \mathrm{MHz}\left({ }^{1} \mathrm{H}\right)$ and $150 \mathrm{MHz}\left({ }^{13} \mathrm{C}\right)$

${ }^{\mathrm{b}} \mathrm{NMR}$ data were measured in $\mathrm{CD}_{3} \mathrm{OD}$ at $500 \mathrm{MHz}\left({ }^{1} \mathrm{H}\right)$ and $125 \mathrm{MHz}\left({ }^{13} \mathrm{C}\right)$ 
Table 5: ${ }^{13} \mathrm{C}$ NMR data of the osidic part of compounds 4-8 in $\mathrm{CD}_{3} \mathrm{OD}$

\begin{tabular}{|c|c|c|c|c|c|}
\hline Position & $4^{a}$ & $5^{b}$ & $6^{b}$ & $7^{a}$ & $8^{a}$ \\
\hline & $\delta_{\mathrm{C}}$ & $\delta_{\mathrm{C}}$ & $\delta_{\mathrm{C}}$ & $\delta_{\mathrm{C}}$ & $\delta_{\mathrm{C}}$ \\
\hline \multicolumn{6}{|l|}{ C-3-Ara } \\
\hline $1^{\prime}$ & 105.7 & 106.8 & 104.6 & 104.7 & 104.7 \\
\hline $2^{\prime}$ & 70.7 & 73.9 & 73.9 & 75.0 & 74.7 \\
\hline $3^{\prime}$ & 82.4 & 80.9 & 81.7 & 80.9 & 81.0 \\
\hline $4^{\prime}$ & 68.1 & 67.2 & 69.3 & 69.0 & 68.8 \\
\hline $5^{\prime}$ & 65.2 & 63.3 & 65.1 & 64.7 & 64.7 \\
\hline \multicolumn{6}{|l|}{ C-2'-Rha } \\
\hline $1^{\prime \prime}$ & & 100.6 & 99.8 & 100.8 & 100.6 \\
\hline $2^{\prime \prime}$ & & 70.7 & 70.9 & 70.5 & 70.5 \\
\hline 3" & & 70.7 & 70.8 & 70.8 & 70.8 \\
\hline $4^{\prime \prime}$ & & 72.4 & 72.5 & 72.5 & 72.4 \\
\hline 5" & & 68.9 & 68.7 & 68.7 & 68.7 \\
\hline 6" & & 16.6 & 16.4 & 16.8 & 16.7 \\
\hline \multicolumn{6}{|l|}{ C-3'-Glc } \\
\hline $1^{\prime \prime \prime}$ & 104.0 & 102.9 & 104.4 & 101.6 & 101.6 \\
\hline $2^{\prime \prime \prime}$ & 76.5 & 73.7 & 76.5 & 80.2 & 80.1 \\
\hline $3^{\prime \prime \prime}$ & 76.3 & 70.7 & 74.4 & 76.9 & 76.9 \\
\hline $4^{\prime \prime \prime}$ & 69.8 & 69.8 & 69.4 & 69.8 & 69.7 \\
\hline $5^{\prime \prime \prime}$ & 73.9 & 70.7 & 77.2 & 76.6 & 76.6 \\
\hline $6^{\prime \prime \prime}$ & 61.0 & 61.0 & 60.8 & 61.1 & 61.1 \\
\hline \multicolumn{6}{|c|}{ C-2"'"-Glc } \\
\hline $1^{\prime \prime \prime \prime}$ & & & 102.0 & 102.7 & 102.6 \\
\hline $2 " \prime \prime$ & & & 82.4 & 73.8 & 73.8 \\
\hline $3^{\prime \prime \prime \prime}$ & & & 76.8 & 76.7 & 76.7 \\
\hline $4 " \prime \prime$ & & & 69.7 & 69.6 & 69.9 \\
\hline $5 " \prime \prime$ & & & 76.6 & 75.8 & 75.9 \\
\hline 6"'" & & & 61.1 & 68.1 & 68.1 \\
\hline C-6"'" & & & & Xyl & Ara \\
\hline $1^{\prime \prime \prime \prime \prime}$ & & & & 104.3 & 104.1 \\
\hline $2^{\prime \prime \prime \prime \prime}$ & & & & 73.3 & 71.0 \\
\hline $3^{\prime \prime \prime \prime \prime}$ & & & & 76.1 & 72.6 \\
\hline $4^{\prime \prime \prime \prime \prime}$ & & & & 69.8 & 68.2 \\
\hline 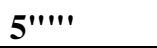 & & & & 65.6 & 65.5 \\
\hline
\end{tabular}

